https://doi.org/10.11646/zootaxa.4387.3.4

http://zoobank.org/urn:Isid:zoobank.org:pub:B53A6B20-5386-4E5A-A00F-A559EDF640DF

\title{
Identification of type materials of the species of Protypotherium Ameghino, 1885 and Patriarchus Ameghino, 1889 (Notoungulata: Interatheriidae) erected by Florentino Ameghino
}

\author{
MERCEDES FERNÁNDEZ $Z^{1,2,3,6}$, JUAN CARLOS FERNICOLA ${ }^{1,2,3}$, \\ ESPERANZA CERDEÑO ${ }^{3,4} \&$ MARCELO A. REGUERO ${ }^{5}$ \\ ${ }^{l}$ Departamento de Ciencias Básicas, Universidad Nacional de Luján, Ruta 5 y Avenida Constitución (6700), Luján, Buenos Aires, \\ Argentina.E-mail: mechi_985@hotmail.com; jctano@yahoo.com \\ ${ }^{2}$ División Paleontología de Vertebrados, Museo Argentino de Ciencias Naturales "Bernardino Rivadavia", Av. Ángel Gallardo 470 \\ (C1405DJR),Ciudad Autónoma de Buenos Aires, Argentina.E-mail:mfernandez@macn.gov.ar; jctano@macn.gov.ar \\ ${ }^{3}$ CONICET. Consejo Nacional de Investigaciones Científicas y Técnicas. \\ ${ }^{4}$ Paleontología, Instituto de Nivología, Glaciología y Ciencias Ambientales, Centro Científico Tecnológico-CONICET-Mendoza, Avda. \\ Ruiz Leals/n, 5500 Mendoza, Argentina.E-mail: espe@mendoza-conicet.gob.ar \\ ${ }^{5}$ División Paleontología de Vertebrados, Facultad de Ciencias Naturales y Museo, Paseo del Bosque s/n, B1900FWA, La Plata, \\ Argentina.E-mail:regui@fcnym.unlp.edu.ar \\ ${ }^{6}$ Corresponding author
}

\begin{abstract}
The first collections of Interatheriinae (Interatheriidae, Notoungulata) were created by the brothers Florentino and Carlos Ameghino, based on fossil specimens collected from diverse outcrops of Argentina and housed at different national institutions. In order to perform a systematic study of the subfamily, it is essential to revise as much specimens as possible, but first of all those that were used to establish the respective species, that is, the type material. Florentino Ameghino never referred to the collection number of the type specimens of the species he erected in any of his publications; this fact added to the occasional absence of illustrations and adequate descriptions, all of which make their identification a complex task. Thus, when studying the species erected by Florentino Ameghino within Protypotherium and Patriarchus, we recognised a lack of correspondence between some specimens that appeared labelled as types in the collections and the original descriptions of these species. In this contribution, we identify the type specimens of the eleven species of Protypotherium and eight of Patriarchus founded by Florentino Ameghino, housed in the Museo Argentino de Ciencias Naturales "Bernardino Rivadavia" (Buenos Aires, Argentina) and the Zoological Museum of the University of Copenhagen (Denmark). Three case studies are presented: a) specimens correctly identified; b) specimens erroneously catalogued as type material; and c) specimens not established as types in Ameghino's catalogue, but herein recognised as such. Lectotype and paralectotype of $P$. antiquum are herein designated.
\end{abstract}

Key words: type specimens, Typotheria, Interatheriinae, Florentino Ameghino

\section{Resumen}

IDENTIFICACIÓN DE LOS MATERIALES TIPO DE LAS ESPECIES DE LOS GÉNEROS PROTYPOTHERIUM AMEGHINO, 1885 Y PATRIARCHUS AMEGHINO, 1889 (INTERATHERIIDAE, NOTOUNGULATA, MAMMALIA) FUNDADAS POR FLORENTINO AMEGHINO. Las primeras colecciones de Interatheriinae (Interatheriidae, Notoungulata) fueron creadas por los hermanos Florentino y Carlos Ameghino, a partir de ejemplares fósiles recolectados en diversos afloramientos de Argentina y alojados en distintas instituciones nacionales. Con el fin de realizar un estudio sistemático de la subfamilia, es esencial revisar la mayor cantidad de ejemplares posible, pero primero aquellos usados para establecer las respectivas especies, es decir, los ejemplares tipo. Florentino Ameghino nunca hizo referencia a los números de colección de los ejemplares tipo de las especies que él fundó en ninguna de sus publicaciones; este hecho, sumado a la ocasional ausencia de ilustraciones y descripciones apropiadas, hace que su identificación se torne una tarea compleja. Es así que, al momento de estudiar las especies fundadas por Ameghino dentro de Protypotherium y Patri- 
archus, reconocimos una falta de correspondencia entre ciertos ejemplares que aparecían catalogados como tipos en las colecciones y las descripciones originales de estas especies. En esta contribución, identificamos los ejemplares tipo de las once especies de Protypotherium y ocho de Patriarchus fundadas por Florentino Ameghino, alojadas en el Museo Argentino de Ciencias Naturales "Bernardino Rivadavia" (Argentina) y el Museo Zoológico de la Universidad de Copenhague (Dinamarca). Se presentan tres casos de estudio: a) ejemplares correctamente tipificados; b) ejemplares erróneamente catalogados como materiales tipo; y c) ejemplares no establecidos como tipos en el catálogo de Ameghino y que aquí se reconocen como tales. Se designan, además, el lectotipo y el paralectotipo de P. antiquum.

Palabras clave: Especímenes tipo, Typotheria, Interatheriinae, Florentino Ameghino

\section{Introduction}

The study of the type specimens is essential in any taxonomic revision, because they are the bearing specimens of a species name when it was first described (ICZN 2000: Art. 73). Unfortunately, almost all fossil mammal species erected between the 19th and 20th centuries by Florentino Ameghino were only a few times accompanied by illustrations and adequate diagnosis, and never published with collection numbers, facts that complicate the identification of the type material. This situation becomes more complex if we consider that F. Ameghino worked in different Argentinean institutions, contributing in the creation of their fossil collections, but he also constructed, along with his brother Carlos, a private collection in which he incorporated specimens belonging to those institutions (Fernicola 2011a, b). There even was a period of time during which Ameghino sold some specimens of his collection to foreign institutions (Vizcaíno 2011; Vizcaíno et al. 2013; Fernicola 2011b). Unfortunately, in this case, there is no appropriated record of which materials were sold, making it even harder to establish the final location of those specimens. As a consequence, some materials, including type specimens, are not housed in their original repository.

The lack of clarity regarding both the location and the typification of some specimens is translated, at least partially, into considering a specimen erroneously lost when it is actually located in another collection and, going even further, into having an erroneous typification of a particular material, which involves the lack of correspondence between the specimens used to erect the species and the materials identified as types in the collections. These problems have already been detected among marsupials (Marshall 1980), armadillos (Ciancio \& Carlini 2008), and the Interatheriinae Interatherium and Icochilus (Fernández et al. 2013), among others.

In this contribution, we present the cases of the Interatheriinae genera Protypotherium and Patriarchus. The interatheriines constitute a group of notoungulates; they are small $(0.5-10 \mathrm{~kg})$, rodent-like, cursorial herbivores (Croft \& Anderson 2008; Townsend \& Croft 2008; Cassini et al. 2012; Elissamburu 2012) with hypsodont dentition, very well represented in the Cenozoic of South America (Hitz et al. 2000). Due to the fact that the problematics explained above are associated to more than just one species of Protypotherium and Patriarchus, we decided to extend the searching and identification of the type materials to all of the species erected by Florentino Ameghino within these two genera. No evaluation of the taxonomic criteria used by Ameghino to erect each has been made here; nevertheless, it is recognised to be necessary, reason why it is being conducted in the framework of an intensive systematic revision of the Subfamily Interatheriinae (M. Fernández's Doctoral Thesis). Here, we present a commented and illustrated catalogue of the type specimens of all of the species of Protypotherium and Patriarchus, along with their present location.

Historical background. The history of the first published interathere goes back to 1882, when Florentino Ameghino mentioned the Genus Protypotherium and its type species, P. antiquum, in a faunal list (Ameghino 1882: 39). However, this mention was not accompanied by any description and, as a result, both genus and species names remained as nomina nuda (ICZN 2000: Art.12) until 1885, when Ameghino formally described the type species. His diagnosis was based on two mandibular specimens collected from the base of the Ituzaingó Formation, Barrancas del Río Paraná (Entre Ríos, Argentina), in levels assignable to the "Mesopotamian" Age (Huayquerian SALMA; late Miocene; Cione et al. 2000). In 1886, Florentino Ameghino became the subdirector of the Museo de La Plata (MLP), and increased its paleontological collection by selling his own personal collection to the provincial government, keeping its guardianship in the MLP (Fernicola 2011b). Francisco Moreno, as director of the MLP, handed those materials he had collected in 1876-1877 in levels of the Santa Cruz Formation (Santa Cruz, Argentina), Santacrucian SALMA (lower Miocene), to F. Ameghino for their study. Among these materials there 
was a maxillary fragment which had been previously used by Moreno (1882: 117) to name, without describing, the genus and species Toxodontophanus australis; these names remained as nomina nuda until 1887, when Ameghino (1887a) formally described Toxodontophanus with T. australis based on the same specimen. Shortly after, over 2000 fossils recovered by Carlos Ameghino from the Santacrucian levels of the Santa Cruz River were deposited at the MLP (Ameghino 1887b; Fernicola 2011a, b). Florentino Ameghino (1887b) described almost all of these specimens and founded two new species within Protypotherium (P. attenuatum and P. praerutilum), and synonimised the name Toxodontophanus with Protypotherium, but Florentino considered T. australis as a valid species, then creating the new combination Protypotherium australe. In 1888, Florentino resigned from his job in the MLP and, as stated by Fernicola (2011a, b), he deviated part of the Santacrucian specimens to his personal collection. As a result, several specimens collected by his brother Carlos in 1887, including type materials, are not located in an unique collection (e.g., Cruz et al. 2013; Vizcaíno et al. 2013), and some specimens that should be at the MLP are not located there. Then, Ameghino (1888) described Protypotherium obstructum based on a lower tooth collected in Monte Hermoso (Buenos Aires), and, in 1889, he described another species of Protypotherium (P. claudum) and erected the Genus Patriarchus with its type species Pa. palmidens, based on specimens collected from Santa Cruz Formation in 1887. Between 1889 and 1894, Carlos Ameghino participated in five expeditions to different Santacrucian regions, where he collected an important amount of fossils later used by his brother (Ameghino 1891, 1894a) to erect, among others, five species within Protypotherium (P. globosum, P. convexidens, P. diversidens, P. compressidens and P. lineare) and seven within Patriarchus (Pa. furculosus, Pa. distortus, Pa. rectus, $P$ a. diastematus, $P$ a. leptocephalus, $P$ a. altus and $P$ a. icochiloides).

\section{Abbreviations:}

Institutional abbreviations. AMNH, American Museum of Natural History, New York, USA; FM, Field Museum of Natural History, Chicago, USA; MACN, Museo Argentino de Ciencias Naturales "Bernardino Rivadavia", Buenos Aires, Argentina; MACN-A, Colección Nacional Ameghino at the MACN, Buenos Aires, Argentina; MLP, Museo La Plata, La Plata, Argentina; YPM, Yale Peabody Museum of Natural History, New Haven, USA; ZMK, Zoological Museum of the University of Copenhagen, Quaternary Zoology Collections, Copenhagen, Denmark.

Anatomical abbreviations. $\mathbf{C} / \mathbf{c}$, upper/lower canine; I/i, upper/lower incisive; $\mathbf{M} / \mathbf{m}$, upper/lower molar; P/p, upper/lower premolar.

Other abbreviations. ICZN, International Code of Zoological Nomenclature; SALMA, South America Land Mammal Age.

\section{Materials and methods}

We initiated our search in two Argentinean institutions, MLP and MACN. Then, we analysed photographs of different specimens - some of them were taken by at least one of the authors and others have been provided by colleagues-located in foreign collections such as Field Museum of Natural History (USA), Peabody Museum of Natural History at Yale University (USA), American Museum of Natural History (USA) and Zoological Museum of the University of Copenhagen (Denmark). Concerning the MLP, we had at our disposal the catalogue of the "Old collections" of the paleontological Collection of the institution.

Although Ameghino did not refer to any collection number in any of his publications, he wrote a well-detailed personal catalogue; this catalogue along with Ameghino's personal collection have been under the guardianship of the MACN since 1935 (Bordas 1936; Simpson 1984; Bond 2000; Fernicola 2011a). Ameghino sometimes labelled specimens individually, while other times he labelled a lot constituted by multiple specimens with a single number. In his catalogue, Ameghino also included a brief reference to the material such as names, a short description of each specimen and the year of collection, as well as indicated the specimens that belonged to the same individual. Regarding this last reference, it is worth mentioning that in certain cases a type specimen appears as collected after the year of the taxon definition and illustration, such is the case of the holotype of Patriarchus palmidens, which was illustrated in 1889, but supposedly collected in 1892-93 according to Ameghino's written catalogue. As a result, we decided not to rely on the year of collection in order to exclude a material as a type specimen, but to rely exclusively on the original descriptions and/or illustrations to establish the true type specimens of Ameghino's species. 
In 1986, Alvaro Mones published a remarkable systematic catalogue of South American fossil vertebrates, in which he summarised the written information in many museums inventories, including the catalogue of the MACN-A which contains the information of Ameghino's handwritten catalogue, and indicated the type specimens of each species. In the case of the MACN (as well as the MLP), Mones (1986: 5) highlighted that the information was taken from the collection files and that he was not able to verify the accuracy of all the copied data and/or the real existence/location of the type materials. For this reason, we can infer that any error in Ameghino's catalogue would have been duplicated by Mones.

In order to identify appropriately the type materials, nearly 700 specimens have been studied in this contribution, including crania, mandibles and more or less complete fragments with teeth. These materials were confronted against the original descriptions published between 1885 and 1894 by F. Ameghino. For the species erected between 1885 and 1889, besides the original available descriptions, we also compared the specimens with the illustrations published by Ameghino (1889: plates 14-15), which, in some cases, complete such descriptions. The species founded between 1891 and 1894 were not illustrated, reason why it was necessary to rely, exclusively, on each original diagnosis (Ameghino 1891, 1894a), which are commonly very brief. Regarding the descriptions made by Ameghino in 1894, we follow the proposal of De Iuliis et al. (2016) in recognizing the priority of the offprint version of that paper (Ameghino 1894a) instead of the printed version (Ameghino 1894b); even being identical works, they differ in their page numbering, which influences the posterior nomenclatural acts. The original descriptions shown in this contribution are transcribed in the original language and are also, for the first time, translated into English.

The measurements indicated in this contribution were taken with a Kendo digital calliper $(0.02 \mathrm{~mm})$. The photographs were taken with a Kodak Digital AZ651 camera. Regarding the selection of type specimens and nomenclatural issues, this contribution follows the regulations established by the ICZN (2000). The dental nomenclature follows Smith \& Dodson (2003) and Hooker (1986), with some considerations taken from Reguero et al. (2003), for the upper dentition, and Vera \& Cerdeño (2014) for the lower dentition.

\section{Systematic palaeontology}

\section{Notoungulata Roth, 1903}

\section{Typotheria Zittel, 1893}

\section{Interatheriidae Ameghino, 1887a}

Interatheriinae Ameghino, 1887a

Protypotherium Ameghino, 1885

Protypotherium Ameghino 1882: 39, nomen nudum. Ameghino, 1885: 81-83.

Type species. Protypotherium antiquum Ameghino 1882: 39, nomen nudum. Ameghino, 1885: 81-83.

Chronological and geographical distribution of the type specimens of the species studied in this contribution. Santacrucian SALMA, Santa Cruz Province (Argentina); Huayquerian SALMA, Entre Ríos Province (Argentina); Montehermosan SALMA, Buenos Aires Province (Argentina).

\section{Protypotherium antiquum Ameghino, 1885}

Lectotype (this contribution). ZMK 21/1877 (ex ZMK 208; Figs. 1 A-B), right mandibular fragment with p4-m3 series.

Paralectotype (this contribution). A toothless fragmented mandible with its symphysis that has not been located. 
(1)
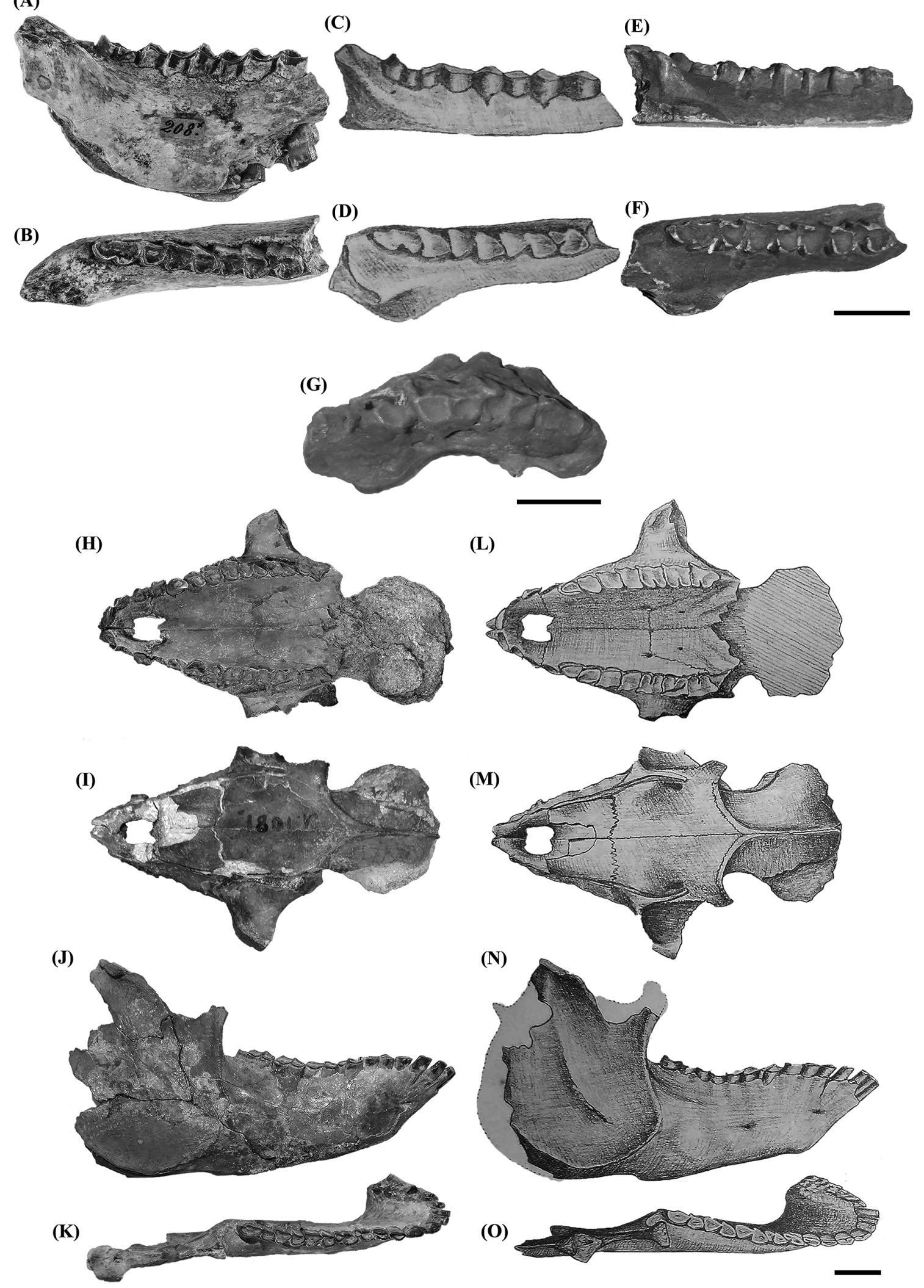

FIGURE 1. Protypotherium antiquum, lectotype ZMK 21/1877, right mandibular fragment with p4-m3, in labial (A) and occlusal (B) views; reproductions of figures 1 (C) and 1a (D) from Ameghino (1889, plate 15); and MACN-A 1288, cast of lectotype, in labial (E) and occlusal (F) views. Protypotherium australe, MACN-A 1338, cast of the holotype, in occlusal view (G). Protypotherium praerutilum, holotype MACN-A 1081, incomplete skull, in ventral (H) and dorsal (I) views; holotype MACN-A 1082, incomplete mandible, in lateral (J) and occlusal (K) views; reproductions of figures $6(\mathbf{L})$ and 6 a $(\mathbf{M})$ from Ameghino (1889, plate 14); reproductions of figures 7 (N) and 7a (O) from Ameghino (1889, plate 14). Scale bar $=10 \mathrm{~mm}$. 


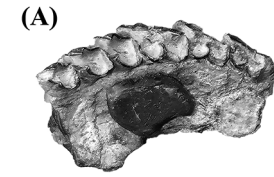

(B)

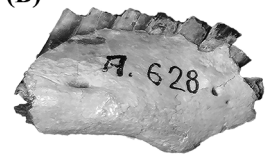

(C)

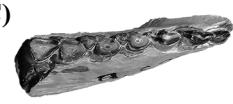

(I)

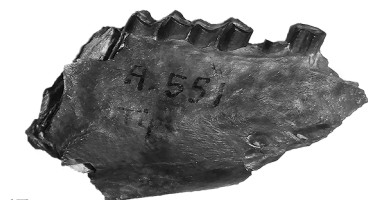

(J)

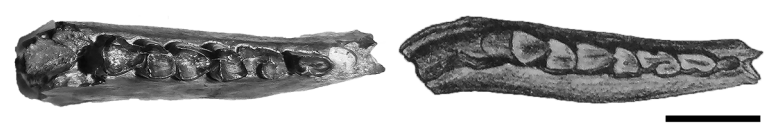

(K)

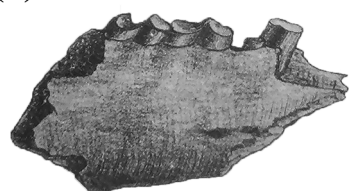

(L)

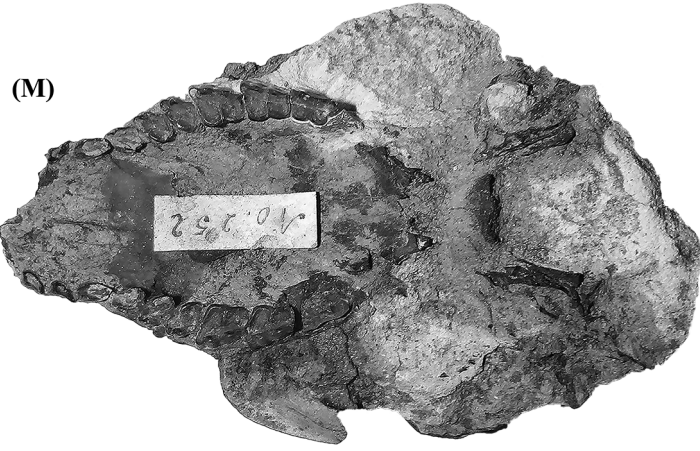

(Q)

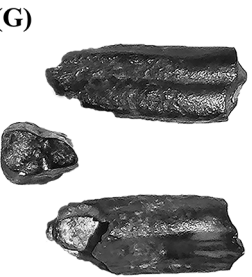

(H)
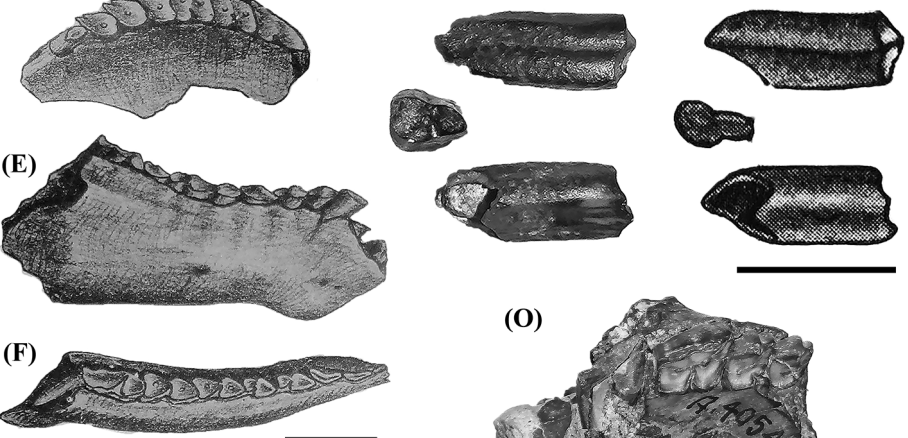

(O)

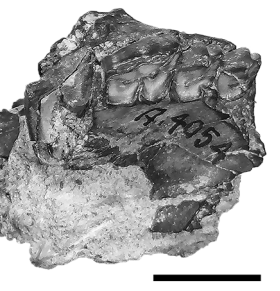

(P)

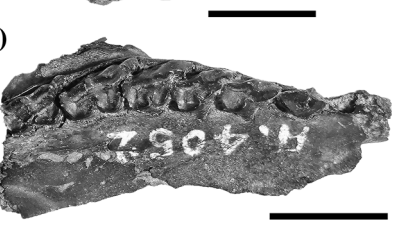

(R)
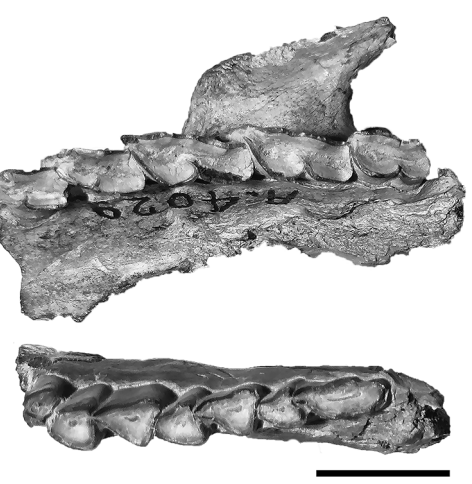

(S)
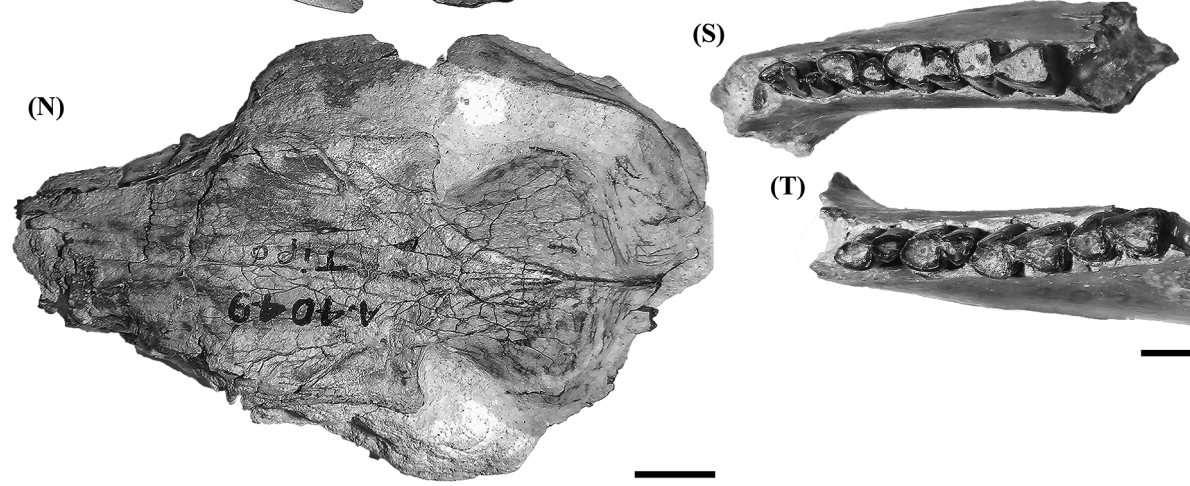

(T)

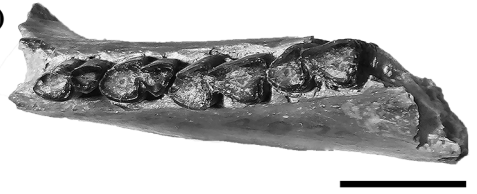

FIGURE 2. Protypotherium attenuatum, syntype MACN-A 524, left maxilla with P2-M3 but lacking P1, in occlusal view (A); syntype MACN-A 628, right fragmented mandible with alveoli of i1-3 and c (broken)-m1 but lacking m2-3, in labial (B) and occlusal (C) views; reproductions of figures 21 (D), 20 (E) and 20a (F) from Ameghino (1889, plate 14). Protypotherium obstructum, holotype MACN-A 1677, lower premolar in labial, oclusal and lingual views (G); reproduction of figure 19 (H) from Ameghino (1889, plate 15). Protypotherium claudum, holotype MACN-A 551, right mandibular fragment with alveolus of p2 and p3-m2, in labial (I) and occlusal (J) views; reproductions of figures 22 (K) and 22a (L) from Ameghino (1889, plate 14). Protypotherium globosum, holotype MACN-A 4049, skull, in ventral (M) and dorsal (N) views. Protypotherium convexidens, holotype MACN-A 4054, right maxillary fragment with P3-M2 (broken), in occlusal view (O). Protypotherium diversidens, holotype MACN-A 4052, right maxillary fragment with alveolus of P1 and P2-M3, in occlusal view (P). Protypotherium compressidens, holotype MACN-A 4029, left maxillary fragment with P3-M3, in occlusal view (Q); holotype MACN-A 4030, left mandibular fragment with $\mathrm{p} 4$ (talonid)-m3, in occlusal view (R). Protypotherium lineare, holotype MACN-A 4039, right mandibular fragment with alveolus of p1 and p2-m1, in occlusal view (S); holotype MACN-A 4038, left mandibular fragment with $\mathrm{p} 3-\mathrm{m} 2$, in occlusal view (T). Scale bar $=10 \mathrm{~mm}$. 
Diagnosis (Ameghino, 1885: 81-83). "[...] El fragmento de sinfisis de la mandíbula inferior que me sirvió de base para la fundación del género, es ancho y aplastado en sentido vertical, muy parecido a Typotherium en su parte cóncava interna, pero más aplastado en su parte inferior y con una depresión semilunar en la parte posterior de la sínfisis. El foramen mentale, situado en la parte sinfisaria, es un agujero elíptico, de unos 6 milimetros de diámetro mayor. Las dos ramas de la mandíbula están tan intimamente unidas formando un solo hueso que en ninguna parte se ve ni el más mínimo rastro de sutura. La parte anterior está rota, pero todavía se distinguen en ella seis alvéolos horizontales en los que sin duda se implantaban seis incisivos. Al nivel del agujero mental, tiene la sinfisis 20 milimetros de ancho y 14 milimetros de alto. La pieza del señor Roth es un pedazo del lado derecho de la mandibula inferior, con las cuatro últimas muelas y parte del alvéolo de otro molar anterior, de modo que el número de muelas era, por lo menos, de cinco en cada lado de la mandíbula inferior. Estas muelas eran sin raíces separadas, abiertas en la base y construidas sobre el mismo tipo general que las de Toxodon y Typotherium, con una capa de esmalte, que parece haber sido continua en algunas muelas, o a lo menos con no tantas interrupciones como en las muelas del género Toxodon y todas en serie continua muy apretadas entre sí. La primera muela existente, que corresponde al cuarto y último premolar, si la dentición fuera completa y normal, es más pequeña que las otras, dividida en dos partes desiguales, una anterior más grande y otra posterior bastante más pequeña; esta división es naturalmente producida por dos surcos perpendiculares opuestos, uno colocado sobre el lado interno y el otro sobre la esquina posteroexterna. Las dos muelas que siguen, primero y segundo verdadero molar, están divididas en dos partes o lóbulos más iguales, por dos surcos opuestos, uno interno, poco marcado y acompañado de una pequeña columna formada por la parte posterointerna del primer lóbulo, y el otro externo, más profundo y que forma en la corona un pliegue entrante parecido al que presentan las muelas de los caballos y varios otros mamíferos de órdenes distintos. La última muela, algo más grande que las demás, está dividida en tres partes o lóbulos formados por tres columnas en cada lado (externo e interno), separados por dos surcos. La corona de las muelas está bastante gastada y excavada en el centro, como las del género Typotherium. Parece que la rama ascendente empezaba a levantarse inmediatamente detrás de la última muela. [...]".

English translation. The fragment of mandibular symphysis used to found the genus is wide and vertically compressed, much similar to Typotherium in its internal concave face, but more compressed at its lower part and with a semilunate depression on its posterior end. The mental foramen is an elliptical opening of about $6 \mathrm{~mm}$ of diameter located in the symphyseal region. Both rami of the jaw are intimately fused into a single bone, without any trace of suture. The anterior part is broken, but there are six horizontal alveoli undoubtedly corresponding to six incisors. At the level of the mental foramen, the symphysis is $20 \mathrm{~mm}$ wide and $14 \mathrm{~mm}$ high. Roth's specimen is a right mandibular ramus, with the last four cheek teeth and the broken alveolus of another anterior one, so that the number of cheek teeth was, at least, five on each side of the mandible. These teeth did not have separated roots, were open at the base and constructed on the same general way as those of Toxodon and Typotherium, with a layer of enamel that seems to have been continuous in some cheek teeth, or at least with less interruptions than in those of the genus Toxodon, and all implanted in a very tight, continuous series. The first cheek tooth, assuming a complete and normal dentition, would correspond to the fourth and last premolar; it is smaller than the molars, divided into two unequal parts, the anterior being rather larger than the posterior; this division is naturally produced by two opposite perpendicular grooves, one placed on the inner side and the other on the posteroexternal region. The first and second true molars are divided into two more equal parts or lobes by two opposite grooves, the internal is little marked and accompanied by a small column formed by the posterointernal part of the first lobe, and the external groove is deeper and forms an infolding in the crown similar to that of the cheek teeth of horses and several other mammals of different orders. The last molar, somewhat larger than the others, is divided into three parts or lobes formed by three columns at each side (external and internal), separated by two grooves. The crown of the molars is rather worn and excavated in the centre, such as those of the genus Typotherium. It seems that the ascending ramus was rising immediately behind the last molar.

Comments. Ameghino (1885: 81-83) described Protypotherium antiquum based on two partial mandibular fragments. One of them is a rolled and shattered, toothless fragmented mandible with its symphysis, which Ameghino (1885: 83) recognised to have been used to name the genus and species in a faunal list of a collection catalogue in 1882. However, as already mentioned (see Historical Background), those names are nomina nuda as acknowledged by him years later (e.g., Ameghino, 1887a). The other specimen was collected in the cliffs of Paraná River (Entre Ríos Province) by Santiago Roth, probably during an excursion in 1881, and later borrowed by Ameghino for its study and the description of all the dental characteristics of the species (Ameghino 1885, 1889). It 
involves a right mandibular ramus with broken alveolus of $\mathrm{p} 3$ and complete $\mathrm{p} 4-\mathrm{m} 3$. As the nomenclatural act that made available the name $P$. antiquum took place in 1885 when Ameghino described both specimens, they are here recognised as the syntypes of the species.

There are no comments on the type material of P. antiquum in Ameghino's catalogue and neither in Mones (1986). Regarding the toothless symphysis, it should be housed at the MLP, because this institution bought Ameghino's collection in 1886, unless Ameghino had deviated the specimen to his posterior personal collection; in such a case, it should be in MACN-A. However, this syntype could not be located in any of these institutions or in ZMK and, unfortunately, it has not been identified in any of the available photographs taken from AMNH, FM and YPM. Nevertheless, we cannot reject the hypothesis that it could be located in another foreigner institution (see Vizcaíno et al. 2013); further searching will corroborate or refute this.

In the case of Roth's specimen, it was further described by Ameghino (1887a, 1889) and even illustrated in his Atlas (Ameghino 1889, plate 15: fig.1); this illustration is herein reproduced in Figures $1 \mathrm{C}-\mathrm{D}$. Roth kept this specimen until he sold it to Dr. V. Lausen, a wealthy Danish citizen settled in Buenos Aires, who sent it to the Zoological Museum, Quaternary Zoology Collections-V, Lausen Collection, University of Copenhagen in Denmark, being housed there since the $25^{\text {th }}$ of November of 1887 (B. E. Kramer, pers. comm. to M. Fernández; M. Reguero's pers. obs.). This specimen has a label handwritten by Roth with the following information: "Protypotherium antiquum Amegh. Delta-Egnen, Entre Ríos. Original Roth (37.), Laussen. 25.11.87. 208*". Original Roth (37.) refers to the number in Roth's catalogue, and 208 refers to an older catalogue number of Museum of Zoology in Copenhagen (ZMK 208). However, nowadays this material is catalogued as ZMK 21/1887 (Figs. 1 A-B). Two casts of ZMK 21/1877 were fortunately kept in MLP and MACN-A: MLP 97-XI-20-1, a complete cast, and MACN-A 1288 (Figs. $1 \mathrm{E}-\mathrm{F}$ ), a cast of the tooth row.

Before this contribution, there were two mentions regarding the type specimen of $P$. antiquum, with different interpretations: Schmidt (2013) considered the missing toothless symphysis to be the holotype, whereas Luna (2015) stated the partial mandible ZMK 21/1887 as such. Although Ameghino (1885) recognised that the missing toothless symphysis was the object that he used to name $P$. antiquum in 1882 (nomen nudum), it is true that the taxonomic conception of $P$. antiquum as well as all of its diagnostic dental features (e.g., p4-m3 rootless, with two continuous and opposite, labial and lingual sulci that separates well-delimited trigonid and talonid; tooth row in a very tight continuous series; $\mathrm{p} 4$ smaller than $\mathrm{m} 1-3$, with the trigonid longer and wider than the talonid; $\mathrm{m} 1-2$ larger than premolars, with talonid longer than trigonid, and labial sulcus deeper than the lingual one; $m 3$ larger than the other cheek teeth, with its talonid with two, labial and lingual, distal grooves that delimit a third lobe) were established based on ZMK 21/1887. At the same time, these characteristics were used later by Ameghino to include and contrast the remaining species within the Genus Protypotherium. Therefore, we designate ZMK 21/1887 as the lectotype of $P$. antiquum and, consequently, the remaining syntype becomes the paralectotype (ICZN 2000: Art. 73.2.2).

Chronological and geographical distribution of the type specimen. Huayquerian SALMA, Entre Ríos Province.

\section{Protypotherium australe (Ameghino, 1887a)}

Holotype. Left maxilla with P3-M3; original piece has not been found, but there are two casts in the MACN: MACN-A 1338 (Fig. 1 G) and MACN-A 1345-46.

Diagnosis (Ameghino 1887a: 63). "Talla comparable a la del Dolichotis patachonica. Corona de los molares superiores fuertemente excavada. Paladar poco profundo y relativamente plano. Lóbulo anterior de los verdaderos molares superiores un poco más ancho que el posterior. [...] De este animal sólo se conoce el maxilar superior izquierdo, con las cinco últimas muelas más o menos rotas, excepto las dos últimas, que están enteras. Ha sido encontrado, como el precedente, por F. P. Moreno, durante su viaje de 1876-1877".

English translation. Size similar to that of Dolichotis patachonica. Crown of upper cheek teeth strongly excavated. Palate shallow and relatively flat. Anterior lobe of upper molars slightly wider than the posterior one. [...] This animal is only known from the left upper jaw, with the last five cheek teeth more or less broken, except for the last two that are complete. It has been found, like the precedent, by F. P. Moreno, during his 1876-1877 exploration. 
Comments. In the original diagnosis, Ameghino (1887a) highlighted that the maxilla collected by Moreno was the only known material of $P$. australe. Shortly after, Ameghino (1887b) completed the former diagnosis by giving the dimensions of a mandibular fragment with at least p1-m3. Once again, Ameghino (1889, plate 14: figs. 9-11, 14-18) expanded the original description of the species and illustrated three isolated upper teeth (I1, P2 and M1; figs. 9-11), three isolated lower teeth (p3, p4 and m1; figs. 14-16), a right maxillary fragment with P4-M3 (fig. 17), and a left mandibular ramus with its teeth (fig. 18). It is worth to mention that he recognised that by 1889 this species was known only by fragmentary materials and that there was no complete upper or lower series available. None of these illustrated specimens is the left maxilla used in the original description as they involve isolated teeth, a mandibular fragment and a right maxilla, which leads us to conclude that the holotype was not illustrated. According to Ameghino's catalogue, MACN-A 3882, an incomplete skull with almost complete dentition (alveoli of both I1 and left I2-3, and complete right I2-M3 and left C-M3), and MACN-A 3884, a mandibular symphysis and its right mandibular ramus, are the type specimens. In contrast, Mones (1986) did not indicate any type specimen, and just mentioned "MLP (-)", meaning that it was supposed to be housed at the MLP but that it could also be lost.

MACN-A 3882 is discarded as the holotype because it does not correspond to the fragmented left maxilla initially described by Ameghino (1887a). In turn, MACN-A 3884 is the mandibular fragment described shortly after (Ameghino 1887b), but it is not part of the type material as this is only composed of one specimen as highlighted by Ameghino (1887a), which is the maxillary fragment that constitutes the holotype. In contrast, there are two identical casts in the Ameghino Collection, MACN-A 1338 and MACN-A 1345-46, which match the original diagnosis as they are the casts of a left maxilla with broken P3, labially incomplete P4-M1 and complete M2-3, strongly excavated tooth row, and M1-3 with anterior lobe slightly wider than the posterior lobe. In addition, Ameghino wrote "Moreno" next to the description of MACN-A 1338 in his catalogue, and "tipo de Toxodontophanus Mo." next to MACN-A 1345-46, a fact that reinforces the inference that they correspond to the maxilla collected by Moreno and, therefore, both are recognised as casts of the holotype.

Unfortunately, the original piece has not been located, as no specimen in the studied collections-by direct observations (e.g., MACN, MLP and ZMK) and/or by means of photographs (e.g., AMNH, FM and YPM) matches the original description of $P$. australe and the casts MACN-A 1338 and MACN-A 1345-46.

Chronological and geographical distribution of the type specimen. Santacrucian SALMA, Santa Cruz Province.

\section{Protypotherium praerutilum Ameghino, 1887b}

Holotype. MACN-A 1081 (Figs. $1 \mathrm{H}-\mathrm{I}$ ), an incomplete skull, and MACN-A 1082 (Figs. $1 \mathrm{~J}-\mathrm{K}$ ), a broken mandible, both belonging to the same individual.

Diagnosis (Ameghino 1887b: 15). "Tamaño más pequeño [que Protypotherium australe]. Ultima muela inferior con la separación del tercer lóbulo apenas indicada. Longitud de las siete muelas inferiores, $35 \mathrm{~mm}$. Alto de la rama horizontal debajo del $\mathrm{m} ., 16 \mathrm{~mm}$ ".

English translation. Smaller size [than Protypotherium australe]. Last lower molar with the separation of the third lobe slightly marked. Length of the seven lower molars, $35 \mathrm{~mm}$. Height of mandibular ramus below $\mathrm{m} 1,16$ $\mathrm{mm}$.

Comments. In 1889, Ameghino expanded the original description of the species by including more characteristics associated to the mandible and its lower dentition. He also featured the skull and its mandible (Ameghino 1889, plate 14: figs. 6-7) along with three isolated lower anterior teeth (i2, i3, c; figs. 8, 12-13). According to Ameghino's catalogue, MACN-A 1081 and MACN-A 1082, skull and mandible of the same individual, are the type materials of this species. Meanwhile, no specimen is indicated as such by Mones (1986).

MACN-A 1081 and MACN-A 1082 match the original Ameghino's (1889) figures, herein reproduced (Figs. 1 $\mathrm{L}-\mathrm{O}$ ). In addition, MACN-A 1082 coincides with the original description as the talonid of its $\mathrm{m} 3$ presents shallow labial and lingual sulci, resulting in a slightly delimitated third lobe, and matches the measurements (length of p1$\mathrm{m} 3=35.36 \mathrm{~mm}$; height of the mandibular ramus below $\mathrm{m} 1=16.7 \mathrm{~mm}$ ) given by Ameghino $(1887 \mathrm{~b})$. All of this supports the identification of the mandible as the type specimen of P. praerutilum, and given that the skull MACNA 1081 belongs to the same individual as the mandible, both specimens constitute the holotype of the species. 
Unfortunately, the anterior lower teeth illustrated in the Atlas (Ameghino 1889, plate 14: figs. 8, 12-13) could not be located and they are considered to be lost. In addition, they do not belong to MACN-A 1082, because this specimen presents all of its anterior lower dentition. It is not evident that Ameghino had these teeth at hand when he described the species two years earlier and, in fact, he did not indicate them as type material in his catalogue as he did with the skull and mandible; consequently, we do not consider them as part of the type material.

On the other hand, in the collection of palaeontology at the MLP, there are twelve fragmented specimens (MLP 12-1815, left mandible with broken $\mathrm{p} 4$ and $\mathrm{m} 1$, MLP 12-1818, left mandible with broken $\mathrm{m} 1$ and $\mathrm{m} 2$, MLP 121819, left m3, MLP 12-1834, right M3, MLP 12-1845, left mandible with p4-m1, MLP 12-1854, left mandible with m2-3, MLP 12-1856, broken symphysis with broken anterior dentition, MLP 12-1877, left mandible with alveoli of p3-4 and m1-2, MLP 12-2031, left $\mathrm{m} 1$ or m2, MLP 12-2041, left maxilla with P4-M2, MLP 12-2084, right maxilla with P4-M2, and MLP 12-2085, maxillae with both P3-M2 series) labelled as paratypes of $P$. praerutilum. These labels were made in the 1960's and are based on the information contained in the handwritten catalogue of the "Old Collections", which was elaborated in the 1930's (M. Reguero's pers. obs.), that is long after the collection of these specimens. Nevertheless, when comparing the information of these labels with the Old Collections catalogue, we noticed that there are many inconsistencies that make us question the veracity of the labelled data. Although there are handwritten indications concerning the type specimens of several species in this catalogue, none of the materials mentioned above is indicated as "paratype", which is in turn a modern terminology never used by Florentino Ameghino. Additionally, and in contrast to the labels, there is no handwritten information concerning the provenance and/or collector of these specimens. We also noticed that in this catalogue, MLP 121854 is assigned to Protypotherium and not to P. praerutilum as it is printed on its label, and that MLP 12-2041, despite its assignation to P. praerutilum, exhibits its $\mathrm{P} 4$ completely molariform (e.g., protocone and hypocone equally developed), a fact that supports its exclusion from Genus Protypotherium. In addition, there is no evidence about who wrote these labels and, consequently, considered these specimens as paratypes of P. praerutilum. Due to these incongruences and to the fact that there is no original tag that could validate their status as paratypes or even confirm that these materials were collected in 1887 by C. Ameghino and later used by Florentino Ameghino to describe $P$. praerutilum, they are all rejected as the paratypes of the species.

Chronological and geographical distribution of the type specimen. Santacrucian SALMA, Santa Cruz Province.

\section{Protypotherium attenuatum Ameghino, 1887b}

Syntypes. MACN-A 524 (Fig. 2 A), left maxilla with P2-M3, and MACN-A 628 (Figs. 2 B-C), right fragmented mandible with alveoli of $\mathrm{i} 1-3$ and the $\mathrm{c}$ (broken)-m1 series.

Diagnosis (Ameghino 1887b: 15). "Tamaño considerablemente menor que el de la especie precedente [Protypotherium praerutilum]. Series dentarias superiores, más arqueadas. Ultima muela inferior sin vestigios del lóbulo tercero sobre el lado externo. Longitud de las cinco últimas muelas inferiores, 21 milímetros. Alto de la rama horizontal, debajo del $\mathrm{m} .1,13 \mathrm{~mm}$ ".

English translation. Considerably smaller in size than the preceding species [Protypotherium praerutilum]. Upper tooth row more arched. Last lower molar without external traces of the third lobe. Length of the last five lower cheek teeth, 21 millimetres. Height of the horizontal ramus below $\mathrm{m} 1,13 \mathrm{~mm}$.

Comments. In 1889, Ameghino expanded the original description of the species by adding more details on the characteristics of upper and lower dentition, and illustrated a fragmented mandible and a maxillary fragment (Ameghino 1889, plate 14: figs. 20-21) herein reproduced in Figures 2 D-F. The mandibular fragment (Ameghino 1889, plate 14: fig. 20) matches the measurements (length of $\mathrm{p} 3-\mathrm{m} 3 \approx 22 \mathrm{~mm}$; height mandibular ramus below $\mathrm{m} 1$ $\approx 12 \mathrm{~mm}$ ) originally given by Ameghino (1887b), so this type specimen was in fact illustrated. According to Ameghino's catalogue, MACN-A 524, a maxilla with P2-M3, is the type specimen. Despite this, Mones (1986) indicated as type "MLP (-)", which means that the type could be housed at the MLP, but that it could also be lost.

MACN-A 524 (Fig. 2 A) matches the original description (Ameghino 1887b) as it is smaller (length of P2-M3 $=23.53 \mathrm{~mm}$ ) than the holotype of $P$. praerutilum (length of left $\mathrm{P} 2-\mathrm{M} 3=29.83 \mathrm{~mm}$ ), and its cheek teeth are arranged in a more arched position. In addition, it is coincident with figure 21 of the Atlas (Ameghino 1889), except for the loss of its P1 and the fact that the illustration presents a shorter M1 and a central fossette on P2, but 
these differences could be associated to some mistakes made by the illustrator given that the remaining features as well as the specimen dimensions and pattern of breakage are the same. In turn, the mandibular fragment MACN-A 628 is broken at the level of $\mathrm{m} 1$ and has lost the remaining molars of the series, which should be present according to Ameghino's (1887b) description, reason why we could not measure p3-m3 length and the height of the mandibular ramus; nevertheless, MACN-A 628 matches the figure 20 of the Atlas (Ameghino 1889: plate 14). Given that MACN-A 524 is a left maxilla and MACN-A 628 is a right partial mandible, it was not possible to evaluate if both articulate with each other. Ameghino did not indicate that they belonged to the same individual (as he used to do when this was the case) and we consider them as representing two different individuals. Therefore, MACN-A 628 and MACN-A 524 are considered the syntypes of P. attenuatum.

On the other hand, there are nine very fragmented mandibular specimens in the MLP (MLP 12-1822, right m3, MLP 12-1823, left m1-2 and broken m3, MLP 12-1830, left m3 with broken talonid, MLP 12-1841, left m2-3, MLP 12-1842, left incomplete $\mathrm{p} 3-\mathrm{m} 1$, MLP 12-1843, right m2-3, MLP 12-1844, right alveolus of $\mathrm{p} 4$ and $\mathrm{m} 1$, MLP 12-1850, right alveolus of $\mathrm{m} 1$ and $\mathrm{m} 2$, and MLP 12-1851, left $\mathrm{m} 3$ ) labelled as paratypes of $P$. attenuatum. However, as it happened with P. praerutilum, we noticed the lack of correspondence between these labels and the Old Collections catalogue, where none of these specimens is highlighted as "paratype" of P. attenuatum, and no indication regarding their provenance and/or collector is provided. Besides, there is no original tag or indication that could confirm their status as paratypes or that they were collected in 1887 by C. Ameghino, or that Ameghino had these specimens with him when describing P. attenuatum. Therefore, they are rejected as paratypes of the species.

Chronological and geographical distribution of the type specimen. Santacrucian SALMA, Santa Cruz Province.

\section{Protypotherium obstructum Ameghino 1888}

Holotype. MACN-A 1677 (Fig. 2 G), lower premolar.

Diagnosis (Ameghino 1888: 14). "Esta especie está representada por un solo premolar inferior, pero de una forma tan distinta de los mismos dientes de las otras especies que indica claramente no puede proceder de ninguna de las ya conocidas. Es el premolar tercero o cuarto de la mandíbula inferior, y difiere de los mismos dientes de las demás especies, por el surco perpendicular externo menos profundo, y por no presentar vestigios del surco interno opuesto. La cara perpendicular interna es así casi plana, con una muy pequeña elevación perpendicular en el medio. Largo de la corona, 0.0045. Es esta la especie más moderna del género".

English translation. This species is represented by a single lower premolar so different from the same teeth of the other known species that clearly indicates that it does not belong to any of them. It is the third or fourth lower premolar, and differs from the same teeth of the other species by the shallower external perpendicular groove and the lack of the opposite internal groove. Thus, the internal perpendicular face is almost flat, with a very small perpendicular elevation in the middle. Length of the tooth crown, $0.0045 \mathrm{~m}$. This is the most modern species of the genus.

Comments. In 1889, Ameghino expanded the original diagnosis of the species by describing with more detail the lower premolar collected at Monte Hermoso (Buenos Aires Province) by his brother Carlos, which was indicated by Florentino as the only assignable material. Florentino Ameghino also illustrated this tooth (Ameghino 1889: plate 14, fig. 14), which is herein reproduced in Figure $2 \mathrm{H}$. No material is indicated as the type in Ameghino's catalogue, but Mones (1986) recognised MACN-A 1677 as such. This specimen is a lower premolar that completely matches the original description (e.g., length equals $4.88 \mathrm{~mm}$; its morphology differs from all the remaining species of the genus as the labial sulcus is extremely shallow, the lingual face is completely flat and lacks any sulcus) and posterior illustration (Ameghino 1889). Therefore, MACN-A 1677 is herein confirmed as the holotype of $P$. obstructum.

Chronological and geographical distribution of the type specimen. Montehermosan SALMA (Ameghino 1889), Buenos Aires Province. 
Holotype. MACN-A 551 (Figs. 2 I-J), right mandibular fragment with alveolus of $\mathrm{p} 2$ and the series p3-m2.

Diagnosis (Ameghino 1889: 480). "Esta especie, de tamaño bastante pequeño, intermedia entre el del Protypotherium praerutilum y el del Protypotherium attenuatum, se aleja de todas las demás por algunos caracteres de importancia. Conozco de ella un fragmento de la rama derecha de la mandíbula inferior, con los dos últimos premolares y los dos primeros verdaderos molares. El $p_{._{3}}$ difiere completamente de la forma que presenta en todas las demás especies. La cara interna es casi plana, presentando una notable analogía con la del Protypotherium obstructum; sin embargo, presenta tres elevaciones perpendiculares poco marcadas, que limitan dos depresiones anchas pero completamente superficiales. La cara externa se distingue por una depresión perpendicular ancha y poco profunda que no forma pliegue entrante en la corona; depresión que reemplaza al surco angosto y profundo que tienen las otras especies en la parte posterior de la cara externa, cuya prolongación en la corona forma un pliegue entrante agudo. La cara perpendicular posterior, en vez de ser más angosta y redondeada, como en las otras especies, es del mismo ancho que el resto de la muela y deprimida perpendicularmente en el medio. La superficie masticatoria es de forma regularmente alargada o elíptica, un poco aplastada en el lado interno, pero no dividida en dos lóbulos desiguales como en las otras especies. Tiene $0^{m} 0035$ de diámetro anteroposterior por $0^{m} 002$ de diámetro transverso. El $p{ }_{4}$ presenta un surco perpendicular interno y otro externo, opuestos, como en casi todas las demás especies; pero los dos lóbulos tienen un tamaño casi igual, siendo el anterior apenas un poco mayor que el posterior. Tiene $0^{m} 004$ de diámetro anteroposterior y $0^{m} 0026$ de diámetro transverso. Los molares primero y segundo están bilobados en el lado interno y en el externo por dos surcos perpendiculares opuestos, como en las otras especies, siendo el lóbulo anterior bastante más pequeño que el posterior. Sobre el lado interno el lóbulo anterior es convexo terminando atrás en una columna ancha y redondeada, pero el lóbulo posterior es deprimido y algo excavado en su parte anterior. Cada una de estas muelas tiene $0^{m} 0065$ de diámetro anteroposterior por $0^{m} 003$ de diámetro transverso. Las cuatro muelas juntas mencionadas $\left(p_{\cdot_{3},}, p_{\cdot 4}, m_{\cdot}, y m_{._{2}}\right)$ ocupan un espacio longitudinal de 21 milimetros. En el fragmento de mandíbula mencionado hay dos agujeros mentonianos posteriores, uno más grande debajo de la parte anterior del p. $y$ otro más pequeño debajo del p. . La rama horizontal debajo del m. tiene 16 milímetros de alto".

English translation. This rather small species, intermediate between Protypotherium praerutilum and Protypotherium attenuatum, differs from all other species by some important characters. I know it from a right mandibular fragment with the last two premolars and the first two molars. The p3 completely differs from the morphology present in all the remaining species of the genus. Its internal face is almost flat, similar to that of Protypotherium obstructum; however, it presents three slightly marked perpendicular elevations that limit two wide but shallow depressions. The external face is distinguished by a wide and shallow perpendicular depression that does not form an infolding in the crown; this depression replaces the narrow and deep posteroexternal groove present in the remaining species. The posterior perpendicular face, instead of being narrow and rounded as in the other species, has the same width as the rest of the premolar and is perpendicularly depressed in the middle. The masticatory surface is regularly elongated or elliptical, somewhat compressed on the internal side, but not divided into two unequal lobes as in the other species. Its anteroposterior diameter is $0.0035 \mathrm{~m}$ and the transverse diameter, $0.002 \mathrm{~m}$. The $\mathrm{p} 4$ presents two opposite, internal and external, perpendicular grooves as in almost all the other species, but both resulting lobes are almost of equal in size, the anterior one hardly larger than the posterior one. Its anteroposterior diameter is $0.004 \mathrm{~m}$ and the transverse diameter, $0.0026 \mathrm{~m}$. The first and second molars are bilobed by two opposite internal and external perpendicular grooves, as in the other species, the anterior lobe being much smaller than the posterior one. The anterior lobe is convex on the internal side and it ends posteriorly in a wide rounded column; the posterior lobe is depressed and somewhat excavated on its anterior region. Each of these molars has an anteroposterior diameter of $0.0065 \mathrm{~m}$ and a transverse diameter of $0.003 \mathrm{~m}$. All cheek teeth together (p3 to $\mathrm{m} 2$ ) occupy a length of $21 \mathrm{~mm}$. The mentioned mandibular fragment presents two posterior mental foramina, the largest one is placed below the anterior region of $\mathrm{p} 3$ and the smallest is below $\mathrm{p} 4$. The horizontal ramus below $\mathrm{m} 1$ is $16 \mathrm{~mm}$ high.

Comments. Ameghino (1889: 480) described this species based on the mandibular fragment later illustrated in his Atlas (Ameghino 1889, plate 14: fig. 22) and herein reproduced in Figures 2 K-L. According to Ameghino's catalogue and to Mones (1986), MACN-A 551 is the holotype of this species. MACN-A 551 matches the original diagnosis and figures, and it is, therefore, confirmed as the holotype of $P$. claudum. 
Chronological and geographical distribution of the type specimen. Santacrucian SALMA, Santa Cruz Province.

\section{Protypotherium globosum Ameghino, 1891}

Holotype. MACN-A 4049 (Figs. 2 M-N), an almost complete skull lacking the left premaxilla.

Diagnosis (Ameghino 1891: 292). "Tamaño bastante más pequeño que el Protypotherium australe (Moreno) Ameghino. Se distingue por los parietales, que se levantan bastante más arriba que los frontales, de superficie globosa, cortos y que atrás descienden hacia abajo de una manera casi repentina. Frente muy ancha y plana; nasales cortos. Longitud del cráneo, 8 centímetros. Diámetro transverso máximo, 53 milímetros. Diámetro interorbitario de los frontales, 3 centímetros. Longitud de la serie dentaria superior, 45 milímetros".

English translation. Considerably smaller size than Protypotherium australe (Moreno) Ameghino. It can be distinguished by its short parietals that rise much higher than the frontals, with a globular surface, and suddenly descend downwards posteriorly. Forehead very broad and flat; nasals short. Length of the skull, 8 centimetres. Maximum transverse diameter, 53 millimetres. Interorbital diameter of the frontals, 3 centimetres. Length of upper tooth row, 45 millimetres.

Comments. Ameghino (1891) described this taxon without any illustration. According to Ameghino's catalogue and to Mones (1986), the incomplete skull MACN-A 4049 is the type material of the species. This specimen matches the original diagnosis (Ameghino 1891) both in morphology (e.g., the most posterior region of the frontals and the anterior portion of the parietals form a convex surface that rapidly descends posteriorly, frontals are wide and flat, and nasals and parietals are short) and measurements (length of the skull $=84.2$ mm; maximum transverse diameter $=53.4 \mathrm{~mm}$; interorbital frontal diameter $=30.1 \mathrm{~mm}$; length of the upper tooth row $=45 \mathrm{~mm}$ ), and it is herein confirmed as the holotype of P. globosum.

Chronological and geographical distribution of the type specimen. Santacrucian SALMA, Santa Cruz Province.

\section{Protypotherium convexidens Ameghino, 1891}

Holotype. MACN-A 4054 (Fig. 2 O), right maxilla with P3-M2 (broken).

Diagnosis (Ameghino 1891: 292). "De tamaño un poco menor que Protypotherium australe (Moreno) Ameghino, del cual se distingue fácilmente por sus molares superiores de cara externa ligeramente ondulada $y$ convexa en su conjunto. Longitud del espacio ocupado por los $p .^{3}$ a m. ${ }^{2}, 19$ milimetros".

English translation. Slightly smaller than Protypotherium australe (Moreno) Ameghino, from which it is easily distinguished by the external face of upper molars softly undulated and convex as a whole. Length occupied by P3 to M2, 19 millimetres.

Comments. Ameghino (1891) described this taxon without any illustration. According to Ameghino's catalogue and to Mones (1986), the maxillary fragment MACN-A 4050 is the type of the species. However, MACN-A 4050 does not match the specimen originally described, because it is a maxillary fragment with P4-M1, with no evidence of recent breaks; in consequence, the specimen MACN-A 4050 cannot be considered as the holotype of the species. Instead, the specimen MACN-A 4054, a maxilla with P3-M1 and broken M2, matches the measurement (length of P3-M2 $=18.9 \mathrm{~mm}$ ) and the original description provided by Ameghino (1891), because it is smaller than the holotype of $P$. australe (length of $\mathrm{P} 3-\mathrm{M} 2 \approx 32 \mathrm{~mm}$ ) and presents upper molars slightly labially undulated. Therefore, MACN-A 4054 is herein considered as the holotype of $P$. convexidens.

Chronological and geographical distribution of the type specimen. Santacrucian SALMA, Santa Cruz Province.

\section{Protypotherium diversidens Ameghino, 1891}

Holotype. MACN-A 4052 (Fig. 2 P), right maxilla with alveolus of P1 and P2-M3. 
Diagnosis (Ameghino 1891: 292). "De tamaño relativamente pequeño. Se distingue fácilmente por los premolares superiores que presentan el surco perpendicular externo, profundo, ancho en la corona, que se angosta $y$ desaparece pronto hacia la base en vez de seguir de un extremo al otro del diente como en las demás especies. Longitud del espacio ocupado por los . $^{2}$ a m. ${ }^{2}, 24$ milimetros".

English translation. Species of relatively small size. It is easily distinguished by the upper premolars with a deep and wide external groove that rapidly narrows and disappears towards the base, instead of being continuous from the top to the basal end of the tooth as in the other species. Length occupied by P2 to M2, 24 millimetres.

Comments. Ameghino (1891) described this taxon but did not figure it. According to Ameghino's catalogue and to Mones (1986), right maxilla MACN-A 4052 is the type specimen of the species. The premolars of MACNA 4052 exhibit the discontinuous external sulcus indicated in the original description, and the length of the series P2-M2 $(24.34 \mathrm{~mm})$ also matches the value provided originally. As a result, this specimen is confirmed as the holotype of $P$. diversidens.

Chronological and geographical distribution of the type specimen. Santacrucian SALMA, Santa Cruz Province.

\section{Protypotherium compressidens Ameghino, 1891}

Holotype. MACN-A 4029 (Fig. 2 Q), left maxillary fragment with P3-M3, and MACN-A 4030 (Fig. 2 R), left mandibular fragment with $\mathrm{p} 4$ (talonid)-m3, of the same individual.

Diagnosis (Ameghino 1891: 292). "Tamaño casi igual a Protypotherium australe, pero con las muelas comprimidas lateralmente y mucho más angostas. Verdaderos molares superiores de cara externa suavemente ondulada. Longitud del $p^{3}$ al m. ${ }^{3}, 28$ milímetros. Ancho máximo de los verdaderos molares superiores, 3 milimetros".

English translation. Almost equal size to Protypotherium australe, but with laterally compressed and much narrower teeth. Upper molars with slightly undulated external face. Length from P3 to M3, 28 millimetres. Maximum width of true upper molars, 3 millimetres.

Comments. Ameghino (1891) did not add any illustration to his description. According to Ameghino's catalogue and to Mones (1986), MACN-A 4029 and MACN-A 4030, fragmented maxilla and mandible, respectively, are the type specimens of the species; following Ameghino's catalogue, both belong to the same individual, a fact that was corroborated by us since they articulate. These specimens are the only available materials assigned to P. compressidens, and both match the original diagnosis (Ameghino 1891) because the upper and lower teeth are strongly labio-lingually compressed. Besides, the length of P3-M3 of MACN-A 4029 is 28.6 $\mathrm{mm}$, and the maximum width of the upper molars (M1 being the widest) is $3.4 \mathrm{~mm}$, which are similar values to those provided by Ameghino (1891). Therefore, we confirm that the individual MACN-A 4029 plus MACN-A 4030 constitute the holotype of $P$. compressidens.

Chronological and geographical distribution of the type specimen. Santacrucian SALMA, Santa Cruz Province.

\section{Protypotherium lineare Ameghino, 1894a}

Holotype. MACN-A 4038 (Fig. 2 S), right mandibular fragment with alveolus of p1, and p2-m1, and MACN-A 4039 (Fig. 2 T), left mandibular fragment with $\mathrm{p} 3-\mathrm{m} 2$ series, both specimens of the same individual.

Diagnosis (Ameghino 1894a: 13-14). "Cette espèce, par la taille se rapproche du P. australe, mais s'en distingue facilement par les deux dernières prémolaires inférieures qui, au lieu d'être implantées obliquement comme dans les autres espèces, sont placées avec leur grand axe dans la même direction de la série dentaire. A conséquence de cette disposition, le sillon vertical, au lieu d'être placé en arrière il est en dehors; ce sillon est très profond, et le lobule postérieur externe de chaque prémolaire est bien développé, formant une colonne étroite mais élevée. Longueur des sept molaires inférieures $38 \mathrm{~mm}$. Hauteur de la mandibule: en dessous de la 2 p. $13 \mathrm{~mm}$.; en dessous de la partie antérieure de là ${ }_{3} \mathrm{~m}$. $20 \mathrm{~mm}$ ".

English translation. This species is close in size to Protypotherium australe, but it is easily distinguished from it by the last two lower premolars that, instead of being obliquely implanted as in the other species, are placed with 
their major axis in the same direction of the tooth row. Due to this position, the vertical groove is placed outside instead of backwards; this groove is very deep, and the posterior lobe of each premolar is externally well developed, forming a narrow and high column. Length of the seven lower teeth: $38 \mathrm{~mm}$. Height of the mandible: below p2, $13 \mathrm{~mm}$; below the anterior region of $\mathrm{m} 3,20 \mathrm{~mm}$.

Comments. Ameghino (1894a) did not add any illustration to the description of P. lineare. In the Ameghino Collection, this species is represented by eight materials. According to Ameghino's catalogue and to Mones (1986), two mandibular fragments, MACN-A 4038 and MACN-A 4039, are the type material of the species; following Ameghino's catalogue, both belong to the same individual. Due to the presence of recent breaks, it is inferred that $\mathrm{m} 3$ got lost. Nevertheless, the measurements available to be taken (height of the mandibular ramus below p2 $=13.7$ $\mathrm{mm}$; below the mesial region the alveolus of left $\mathrm{m} 3=19.8 \mathrm{~mm}$ ) match those provided by Ameghino (1894a). Regarding the remaining six specimens assigned to $P$. lineare, five of them are too incomplete mandibular fragments, smaller than MACN-A 4038 and MACN-A 4039, and those with their $\mathrm{p} 2$ and/or m3 do not match the original measurements regarding the height of the mandible; then, they are all discarded as type specimens. The sixth specimen, MACN-A 4040 (partial right mandible with c, alveoli of p1-3 and complete p4-m3), is closer in size to the original mandibular fragment, but it is still smaller (height of the mandibular ramus below $\mathrm{p} 2=12.48$ $\mathrm{mm}$; below $\mathrm{m} 3=17.36 \mathrm{~mm}$ ), and lacks its $\mathrm{p} 3$ (the alveolus is filled with sediment), which also allows discarding it as the type specimen because Ameghino specifically described p3-4. Consequently, the individual MACN-A 4038 plus MACN-A 4039 is confirmed as the holotype of $P$. lineare.

Chronological and geographical distribution of the type specimen. Santacrucian SALMA, Santa Cruz Province.

\section{Patriarchus Ameghino, 1889}

Type species. Patriarchus palmidens Ameghino, 1889: 481.

Chronological and geographical distribution of the type specimens of the species studied in this contribution. Santacrucian SALMA, Santa Cruz Province (Argentina).

\section{Patriarchus palmidens Ameghino, 1889}

Holotype. MACN-A 9651a (Figs. 3 A-C), mandibular symphysis with right i1-p1 and left i1-2 and the alveolus of i3.

Diagnosis (Ameghino 1889: 481). "Es la única especie de este género que conozco hasta ahora; y a juzgar por la parte anterior de la mandibula, tuvo una talla bastante mayor que el Protypotherium antiquum. La sinfisis es muy comprimida lateralmente y sumamente angosta adelante, como que hasta el mismo par de incisivos anteriores están colocados no adelante en sentido transversal, según es de regla en la generalidad de los mamíferos, sino a los lados, en la misma línea longitudinal que todo el resto de la dentadura, lo que le da a esta región un aspecto completamente particular. Cada uno de estos incisivos tiene una corona cuyo diámetro anteroposterior aumenta desde la base a la cúspide, siendo ella sumamente comprimida en sentido transversal, con la cara interna bilobada por un surco perpendicular angosto y profundo en su parte superior, pero que se pierde hacia la base del diente y con la cara externa lisa y convexa. El canino tiene absolutamente la misma forma que los incisivos. Estos cuatro dientes están implantados en la mandíbula inclinados oblicuamente adelante de una manera cada vez más acentuada a partir del canino hasta los incisivos internos, los que se dirigen hacia adelante de una manera casi horizontal. Cada uno de estos dientes tiene una corona de 0"004 a $0^{n} 0045$ de diámetro anteroposterior, por $0^{m} 001$ a $0^{m} 0015$ de diámetro transverso. El p., está implantado verticalmente, con los dos surcos opuestos colocados en los dos últimos tercios de cada cara, angostos y poco profundos. El lóbulo anterior es mucho mayor, más ancho y de forma elíptica; el lóbulo posterior mucho más pequeño, es también más angosto y de forma casi circular. Este diente tiene $0^{m} 0045$ de diámetro anteroposterior por $0^{m} 0023$ de diámetro transverso. Los tres incisivos, el canino y el primer premolar ocupan juntos en línea recta un espacio longitudinal de 25 milimetros. La sinfisis tiene 10 milímetros de largo y es profundamente excavada en su cara interna". 

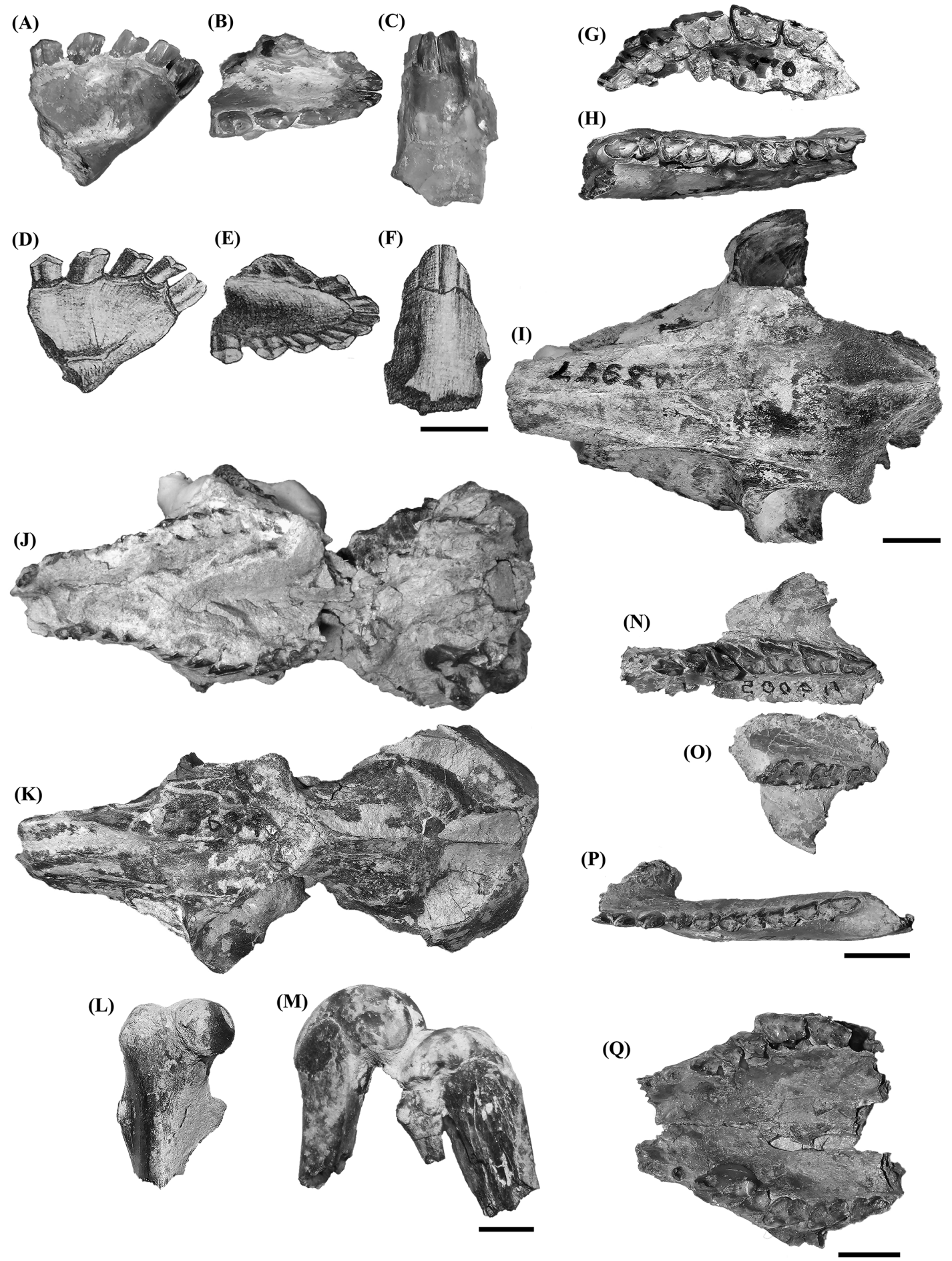

FIGURE 3. Patriarchus palmidens, holotype MACN-A 9651a, mandibular symphysis with right i1-p1 and left i1-2 and the alveolus of i3, in labial (A), occlusal (B) and antero-labial (C) views; reproductions of figures 2 (D), 2a (E) and 2 b (F) from Ameghino (1889, plate 15). Patriarchus furculosus, syntype MACN-A 3970, left maxillary fragment with P2-M3, in occlusal view (G); syntype MACN-A 3972, right mandibular fragment with p2-m3, in occlusal view (H); syntype MACN-A 3977 , incomplete skull, dorsal view (I). Patriarchus distortus, holotype MACN-A 9634 to MACN-A 9638: MACN-A 9634, skull, ventral (J) and dorsal (K) views; MACN-A 9636, proximal epiphysis of right femur, in anterior view (L); MACN-A 9637 and MACN-A 9638, proximal epiphyses of right tibia and fibula, articulated with the distal epiphysis of right femur, in lateral view (M). Patriarchus rectus, holotype MACN-A 4005, right maxillary fragment (vertically rotated) with alveolus of C and series P1-M3, in occlusal view (N); holotype MACN-A 4006, left maxillary fragment (vertically rotated) with M1-3, in occlusal view (O); holotype MACN-A 4007, mandibular fragment with incomplete symphysis, broken alveoli of left and right i1-2 and complete left i3-m3 series, in occlusal view (P). Patriarchus diastematus, holotype MACN-A 4044, two maxillae with alveoli of C-P1 and right P2-M3 and left P2-M2, in occlusal view (Q). Scale bar = $10 \mathrm{~mm}$. 


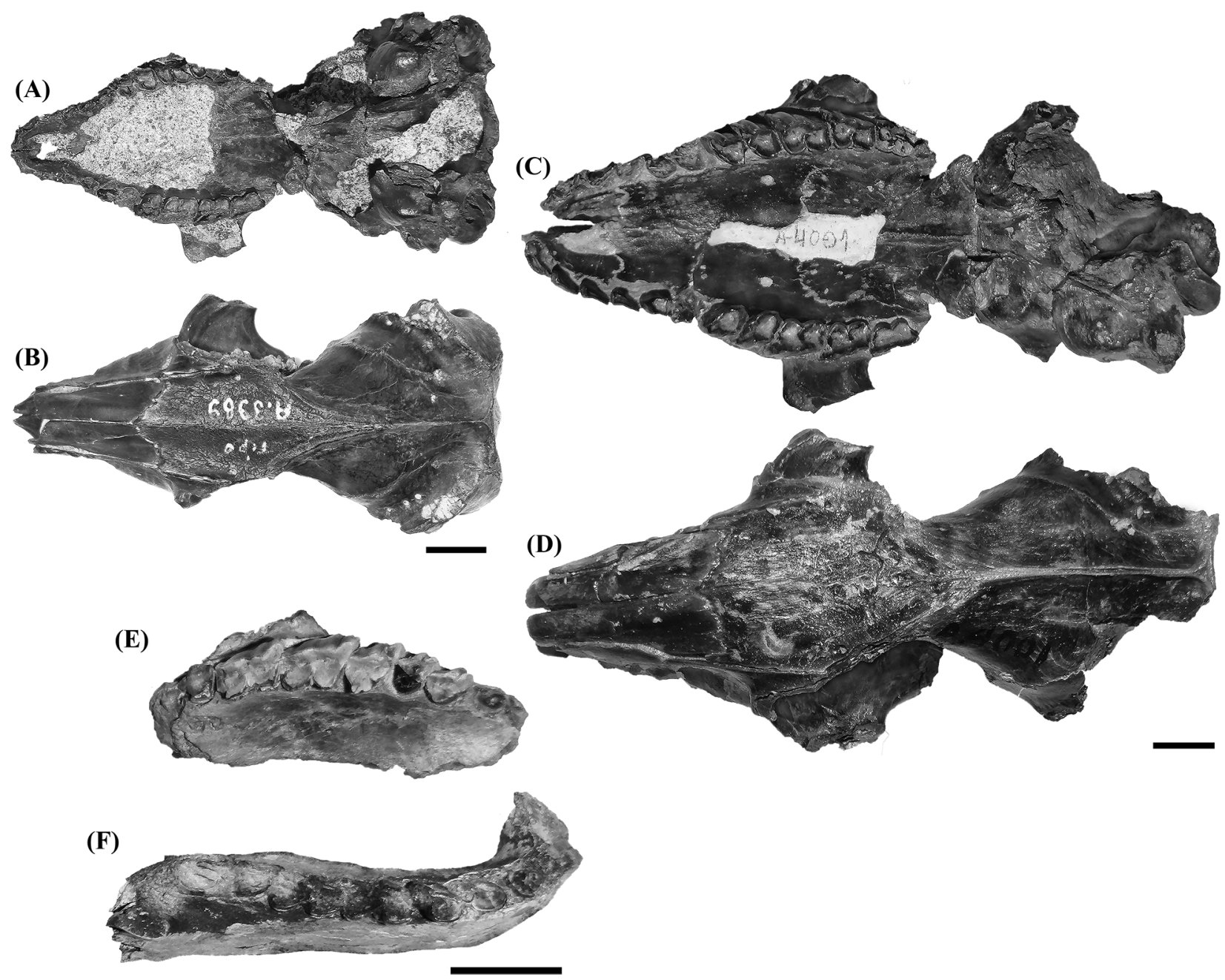

FIGURE 4. Patriarchus leptocephalus, holotype MACN-A 3989, incomplete skull, in ventral (A) and dorsal (B) views. Patriarchus altus, holotype MACN-A 4001, incomplete skull, in ventral (C) and dorsal (D) views. Patriarchus icochiloides, holotype MACN-A 4021, right maxillary fragment with alveolus of P1 and P2-M3, in occlusal view (E); holotype MACN-A 4022 , right mandibular fragment with alveoli of p2-3 and p4-m3, in occlusal view (F). Scale bar $=10 \mathrm{~mm}$.

English translation. This is the only species of this genus so far known. Based on the size of the anterior part of the mandible, it was considerably larger than Protypotherium antiquum. The mandibular symphysis is very laterally compressed and notably narrow anteriorly, so that the anterior incisors are not transversally positioned as generally seen in mammals, but laterally in the same longitudinal line as the remaining teeth, a fact that gives a completely particular aspect to this region. Each incisor exhibits its anteroposterior diameter increasing from the base to the tip, the latter highly compressed transversely, with its internal face bilobed by means of a narrow and deep perpendicular groove that disappears towards the base, and with its external face smooth and convex. The canine has the same morphology as the incisors. These four teeth are obliquely implanted in the jaw obliquely inclined forward, mainly the internal incisors that are nearly horizontally placed. The crown of each of these teeth has $0.004 \mathrm{~m}$ to $0.0045 \mathrm{~m}$ of anteroposterior diameter and $0.001 \mathrm{~m}$ to $0.0015 \mathrm{~m}$ of transverse diameter. The $\mathrm{p} 1$ is vertically implanted, with two opposite narrow and shallow grooves placed in the last two thirds of each face. The anterior lobe is much larger, wider and elliptical; the posterior lobe is much smaller, also narrow and almost circular. This tooth has $0.0045 \mathrm{~m}$ of anteroposterior diameter and $0.0023 \mathrm{~m}$ of transverse diameter. The three incisors, the canine and the first premolar occupy together, in a straight line, a length of $25 \mathrm{~mm}$. The symphysis is $10 \mathrm{~mm}$ long and is deeply excavated internally. 
Comments. Ameghino (1889: 481) founded this taxon based only on a mandibular symphysis that was illustrated in his Atlas (Ameghino 1889, plate 15: figs. 2-3) and herein reproduced (Figs. 3 D-F). According to Ameghino's catalogue, MACN-A 37 (a complete skull), MACN-A 38 (a right mandibular branch associated to MACN-A 37), and MACN-A 4045 (a right mandibular ramus) are the type specimens of this species. Instead, after Mones (1986), only MACN-A 4045 is the type material. Nevertheless, none of these specimens matches the original description or the illustrated symphysis (Ameghino 1889) and, as a result, they are discarded as the type of the species. In Ameghino's catalogue there are 22 other specimens assigned to Pa. palmidens, nine of which are lost. Among the remaining, a symphysis located within the lot MACN-A 9651, and herein differentiated as MACN-A 9651a, matches the original description and the illustrated symphysis (Ameghino 1889). Consequently, it is recognised as the holotype of $P$ a. palmidens. This lot includes other five fragmented mandibles (identified by us as MACN-A 9651b to MACN-A 9651f) that belong to different individuals. These specimens are discarded as part of the type series because, on the one hand, Ameghino (1889) used an unique specimen to erect the species and, on the other hand, none of them presents anterior dentition, but cheek teeth which would have been described by Ameghino in case he had had these teeth at hand.

Chronological and geographical distribution of the type specimen. "Notohippidian" (Ameghino 19001902, 1906), Santacrucian SALMA, Santa Cruz Province.

\section{Patriarchus furculosus Ameghino, 1891}

Syntypes. MACN-A 3970 (Fig. 3 G), left fragmented maxilla with P2-M3, MACN-A 3971, fragments of the right maxilla, MACN-A 3972 (Fig. 3 H), right mandibular fragment with p2-m3, MACN-A 3973, distal region of the humerus, MACN-A 3974, calcaneus, and MACN-A 3975-76, broken vertebrae, all from the same individual; and MACN-A 3977 (Fig. 3 I), incomplete skull.

Diagnosis (Ameghino 1891:292-293). "Es la especie de mayor tamaño. El p2 es mucho más prolongado en el lado interno; los frontales se prolongan adelante entre los nasales por un trecho considerable en forma de cuña sobre la línea media. Las ondulaciones externas de los verdaderos molares inferiores son apenas acentuadas. Longitud del espacio ocupado por la dentadura inferior, 57 milimetros. Diámetro interorbitario de los frontales, 33 milimetros. Longitud de los nasales sobre la línea media, 28 milimetros".

English translation. It is the largest species. The $\mathrm{p} 2$ is much longer on the internal side. Frontals extend forward between the nasals in a long, wedge-shaped median projection. The external undulations of the lower molars are barely pronounced. Length occupied by the lower teeth, 57 millimetres. Interorbital diameter of the frontals, 33 millimetres. Length of the nasals on midline, 28 millimetres.

Comments. Ameghino (1891) founded this taxon without illustrating it. According to Ameghino's catalogue, MACN-A 3970 to MACN-A 3976 are the type specimens of the species and belong to the same individual. Despite this, Mones (1986) indicated "MACN ?", which means doubt or lack of information about the type that could be housed at the MACN. The fragmented specimens MACN-A 3970 and MACN-A 3972 match the original description (Ameghino 1891), because they exhibit a larger size (length of $\mathrm{P} 2-\mathrm{M} 3=36.5 \mathrm{~mm}$; length of $\mathrm{p} 2-\mathrm{m} 3=$ $41.05 \mathrm{~mm}$ ) than the remaining specimens, p2 is lingually longer, and m1-3 are slightly labially undulated. However, they are not complete enough to show the described features of the cranial roof, and the breakage on this area does not seem to be recent. On the other hand, MACN-A 3977 is an incomplete skull of another individual, whose fronto-nasal suture shows the described wedge-shaped median projection, and the only measurement available to be taken (length of the nasal on midline $=28 \mathrm{~mm}$ ) also matches the original description. Therefore, MACN-A 3970 to MACN-A 3976 and MACN-A 3977, which correspond to two different individuals, are considered the syntypes of $P$ a. furculosus.

Chronological and geographical distribution of the type specimen. Santacrucian SALMA, Santa Cruz Province.

\section{Patriarchus distortus Ameghino, 1891}

Holotype. MACN-A 9634 (Figs. 3 J-K), incomplete skull, MACN-A 9635, incomplete coxal (lost), MACN-A 
9636 (Fig. 3 L), proximal epiphysis of right femur, MACN-A 9637 and MACN-A 9638, proximal epiphyses of right tibia and fibula articulated to each other and with the distal epiphysis of right femur (Figs. $3 \mathrm{M}$ ), all specimens of the same individual.

Diagnosis (Ameghino 1891: 293). "De tamaño casi igual a la precedente [Patriarchus furculosus], de la cual se distingue por los frontales que no envían prolongamiento internasal hacia adelante. Longitud del cráneo, 102 milimetros. Longitud de la serie dentaria superior, 57 milímetros. Ancho interorbital de los frontales, 32 milímetros. Longitud de los nasales sobre la línea media, 29 milimetros".

English translation. Size almost equal to the previous one [Patriarchus furculosus], from which it is distinguished by the frontals that do not exhibit an anterior projection between nasals. Length of the skull, 102 millimetres. Length of upper tooth row, 57 millimetres. Interorbital width of the frontals, 32 millimetres. Length of the nasals on the midline, 29 millimetres.

Comments. Ameghino (1891) did not add any illustration to his description. No specimen is indicated as the type material in Ameghino's catalogue or in Mones (1896). Among the specimens within the Ameghino Collection, MACN-A 9622 (incomplete skull), MACN-A 9639 (incomplete palate) and MACN-A 9640 (mandibular fragment) are discarded as type specimens because, on the one hand, MACN-A 9640 is a partial mandible and, on the other hand, MACN-A 9622 and MACN-A 9639 are incomplete cranial elements from which only a few measurements can be taken, all of which, in turn, do not match the original measurements provided by Ameghino (1891). In contrast, the skull MACN-A 9634 (Figs. $3 \mathrm{~J}-\mathrm{K}$ ) shows the morphology originally described for the fronto-nasal suture, without an internasal frontal projection, and the measurements available to be taken (skull length $=102.1 \mathrm{~mm}$; length of the upper tooth row $=56.5 \mathrm{~mm}$; length of the nasals on the midline $=28.9 \mathrm{~mm}$ ) are coincident with those indicated by Ameghino (1891). This material is accompanied by some postcranial elements (MACN-A 9635 to MACN-A 9638) that would belong to the same individual according to the catalogue. Therefore, MACN-A 9634 to MACN-A 9638 constitute the holotype of Pa. distortus.

Chronological and geographical distribution of the type specimen. Santacrucian SALMA, Santa Cruz Province.

\section{Patriarchus rectus Ameghino, 1891}

Holotype. MACN-A 4005 (Fig. 3 N), right maxilla with alveolus of C and series P1-M3; MACN-A 4006 (Fig. 3 O), left maxillary fragment with series M1-3; and MACN-A 4007 (Fig. 3 P), mandibular fragment with incomplete symphysis, broken alveoli of left and right i1-2 and complete left series i3-m3, all of them of the same individual.

Diagnosis (Ameghino 1891: 293). "De tamaño una mitad menor que las especies precedentes [Patriarchus furculosus $y$ Patriarchus distortus] y de series dentarias superiores casi rectas, P3 a M2 mucho más prolongados en el lado interno. Incisivos intermedios inferiores más aplastados de arriba abajo. Longitud de la serie dentaria inferior, 43 milimetros. Ancho interorbitario de los frontales, 24 milimetros".

English translation. One half smaller than the preceding species [Patriarchus furculosus and Patriarchus distortus], with upper tooth rows almost straight, P3 to M2 much longer on the internal side. Lower median incisors more flattened. Length of the lower tooth row, $43 \mathrm{~mm}$. Interorbital width of the frontals, $24 \mathrm{~mm}$.

Comments. Ameghino (1891) erected this species but did not illustrate any specimens of it. According to Ameghino's catalogue and to Mones (1986), the maxillary fragments MACN-A 4005 and MACN-A 4006, and the fragmented mandible MACN-A 4007, all of the same individual, are the type materials of this species. These specimens match the original diagnosis as they are smaller (length of $\mathrm{P} 1-\mathrm{M} 3=30.5 \mathrm{~mm}$; length of $\mathrm{P} 2-\mathrm{M} 3=27.5$ $\mathrm{mm}$; length of $\mathrm{p} 2-\mathrm{m} 3=29.23 \mathrm{~mm}$ ) than the type material of $P$ a. furculosus (length of $\mathrm{P} 2-\mathrm{M} 3=36.5 \mathrm{~mm}$; length of $\mathrm{p} 2-\mathrm{m} 3=41.05 \mathrm{~mm}$ ) and $\mathrm{Pa}$. distortus (length of $\mathrm{P} 1-\mathrm{M} 3=37.3 \mathrm{~mm}$ ), and the incomplete palate (MACN-A 4005 plus MACN-A 4006) exhibits almost straight upper tooth rows. It is noteworthy that there is no evidence of the frontals in MACN-A 4005 and MACN-A 4006, so it was not possible to measure the interorbital width of these elements. Additionally, the length occupied by the left lower tooth row $(\sim 41 \mathrm{~mm})$ of MACN-A 4007 differs from the value provided by Ameghino (1891), but this is due to the breakage of the mandibular incisor area. Nevertheless, MACN-A 4005 to MACN-A 4007 are confirmed as the holotype of Pa. rectus.

Chronological and geographical distribution of the type specimen. Santacrucian SALMA, Santa Cruz Province. 
Holotype. MACN-A 4044 (Fig. 3 Q), two maxillae with alveoli of left and right C-P1, right P2-M3 and left P2M2.

Diagnosis (Ameghino 1891: 293). "Del mismo tamaño que la especie precedente [Patriarchus rectus], o apenas algo mayor, de la cual se distingue por el P1 pequeño, cilíndrico y separado del que sigue por un pequeño diastema. Series dentarias superiores un poco más arqueadas. Longitud del P2 al M3, 29 milímetros. Ancho del paladar entre los M3, 18 milimetros; ancho entre los M1, 20,5 milimetros; ancho entre los P2, 13 milimetros".

English translation. Same size as the preceding species [Patriarchus rectus] or slightly larger, from which it is distinguished by its small, cylindrical P1, separated from the following premolar by a small diastema. Upper tooth row a little more arched. Length from P2 to M3, 29 millimetres. Width of the palate between M3s, 18 millimetres; between M1s, 20.5 millimetres; between P2s, 13 millimetres.

Comments. Ameghino (1889) described this species without providing any illustration of it. In the Ameghino Collection, Pa. diastematus is represented just by one specimen. According to Ameghino's catalogue and to Mones (1986), maxilla MACN-A 4044 is the type material. This specimen matches the original description because it presents a slightly larger size (length of $\mathrm{P} 2-\mathrm{M} 3=28.1 \mathrm{~mm}$ ) to that of the holotype of Pa. rectus (length of P2-M3 $=27.5 \mathrm{~mm})$ and, according to its alveolus, $\mathrm{P} 1$ is small and cylindrical and is separated from P2 by a small diastema $(\sim 1.4 \mathrm{~mm})$. Besides, all the measurements (length of $\mathrm{P} 2-\mathrm{M} 3=28.88 \mathrm{~mm}$; width of the palate between both $\mathrm{M} 3=$ $19 \mathrm{~mm}$; width of the palate between both $\mathrm{M} 1=20.8 \mathrm{~mm}$; width of the palate between both $\mathrm{P} 2=13.7 \mathrm{~mm}$ ) coincide with those provided by Ameghino (1891). As a result, MACN-A 4044 is confirmed as the holotype of Pa. diastematus.

Chronological and geographical distribution of the type specimen. Santacrucian SALMA, Santa Cruz Province.

\section{Patriarchus leptocephalus Ameghino, 1891}

Holotype. MACN-A 3989 (Figs. 4 A-B), almost complete skull.

Paratype. MACN-A 3990, left cranial fragment with complete I1-M3 series, and MACN-A 3991, complete left mandibular ramus with i1-m3 series, both of the same individual.

Diagnosis (Ameghino 1891: 293). "Tamaño pequeño, pero poco mayor aun que el de la especie precedente [Patriarchus diastematus]. Frontales muy angostos; hocico angosto y prolongado; paladar muy angosto adelante. Toda la forma del cráneo angosta y prolongada. Longitud del cráneo, 82 milímetros; ancho interorbital de los frontales, 21 milímetros; longitud de los frontales sobre la línea media, 21 milímetros. Adelante, los frontales penetran un poco entre los nasales".

English translation. Species of small size, but slightly larger than the previous species [Patriarchus diastematus]. Frontals are very narrow; snout is narrow and long; palate very narrow anteriorly. The whole skull is narrow and long. Length of the skull, 82 millimetres; interorbital width of the frontals, 21 millimetres; length of the frontals on the midline, 21 millimetres. Anteriorly, the frontals slightly penetrate the nasals.

Comments. Ameghino (1891) described this taxon without illustrating any specimens of it. According to Ameghino's catalogue the skull MACN-A 3989 is the type of this species, whereas both incomplete skull MACN-

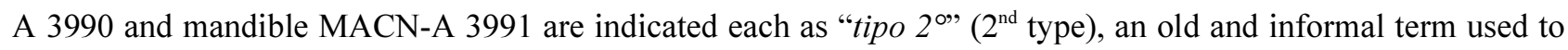
refer to a paratype (C. Sciosia, pers. comm.). Mones (1986) also indicated MACN-A 3989 to MACN-A 3991 as the type specimens of the species, but did not make a distinction between type and $2^{\text {nd }}$ type. The skull MACN-A 3989 matches the original diagnosis as it is slightly larger (length of P2-M3 $=30.2 \mathrm{~mm}$ ) than the holotype of $P a$. diastematus (length of $\mathrm{P} 2-\mathrm{M} 3=28.1 \mathrm{~mm}$ ), the frontals penetrate the nasals, the rostrum is long and the palate is anteriorly narrow; and almost all the measurements (length of the skull $=83.45 \mathrm{~mm}$; intraorbital width of the frontals $=22 \mathrm{~mm}$ ) also match those given by Ameghino (1891). Just the length of the frontals on the middle line $(31 \mathrm{~mm})$ is greater than the length $(21 \mathrm{~mm})$ provided by the author. Nevertheless, this was likely a typing error, because Ameghino established that the frontals were 'very narrow', which is contradictory with the same measure indicated for both the width and length of the frontals $(21 \mathrm{~mm})$. MACN-A 3990 is not complete enough to take any of the measurements given by Ameghino, but it cannot be discarded as part of the paratype, because it does not 
contradict the diagnosis and the author recognised this specimen as $2^{\text {nd }}$ type when he acknowledged MACN-A 3989 as type in his catalogue. As MACN-A 3991 is a partial mandible of the same individual as MACN-A 3990, it is also recognised in this contribution as part of the paratype of $\mathrm{Pa}$. leptocephalus. Regarding the remaining ten specimens assigned to the species in Ameghino's catalogue, MACN-A 9653 is a cranial element, but only the length of the skull $(83 \mathrm{~mm})$ resembles Ameghino's (1891) diagnosis, so it is discarded as part of the type series. The other nine catalogued materials are fragmented mandibles and, consequently, discarded as the type specimens; among them, only MACN-A 11191 is currently within the collection.

In summary, MACN-A 3989 is confirmed as the holotype of Pa. leptocephalus and the individual MACN-A 3990 plus MACN-A 3991 as the paratype of the species.

Chronological and geographical distribution of the type specimen. Santacrucian SALMA, Santa Cruz Province.

\section{Patriarchus altus Ameghino, 1891}

Holotype. MACN-A 4001 (Figs. 4 C-D), almost complete skull.

Paratype. MACN-A 3999, incomplete skull, and MACN-A 4000, incomplete mandible, both of the same individual.

Diagnosis (Ameghino 1891: 293). "Igual conformación general que la especie precedente [Patriarchus leptocephalus], pero de tamaño mucho mayor; rostro más elevado y paladar un poco más ancho adelante. Longitud del cráneo, 102 milimetros; longitud de la serie dentaria superior, 59 milímetros; ancho interorbital de los frontales, 28 milimetros; longitud de los frontales, 30 milimetros. Los frontales no penetran adelante entre los nasales".

English translation. Same general configuration as the preceding species [Patriarchus leptocephalus], but much larger; higher rostrum and palate a little wider anteriorly. Length of the skull, 102 millimetres; length of upper tooth row, 59 millimetres; interorbital width of the frontals, 28 millimetres; length of the frontals, 30 millimetres. Frontals do not penetrate forward between the nasals.

Comments. Ameghino (1891) described this species, but did not add any figure of it. According to Ameghino's catalogue, the skull MACN-A 4001 is the type of this species, whereas the cranial fragment MACN-A

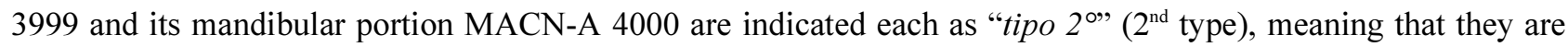
paratypes. Mones (1986) also indicated MACN-A 3999 to MACN-A 4001 as the type specimens of Pa. altus, but did not distinguish between type and $2^{\text {nd }}$ type. The skull MACN-A 4001 matches the original diagnosis as it is larger (length of $\mathrm{C}-\mathrm{M} 3=45.05 \mathrm{~mm}$ ) than the holotype of Pa. leptocephalus (length of $\mathrm{C}-\mathrm{M} 3=37.35 \mathrm{~mm}$ ), its rostrum is more elevated and the anterior region of the palate is wider. All the measurements (skull length $=103.25$ $\mathrm{mm}$; length of the upper tooth row $=58.55 \mathrm{~mm}$; interorbital width of the frontals $=29.26 \mathrm{~mm}$; length of the frontals $=33 \mathrm{~mm}$ ) also match those provided by Ameghino (1891). As a result, we confirm MACN-A 4001 as the holotype of $\mathrm{Pa}$. altus. In the case of the individual MACN-A 3999 plus MACN-A 4000, it is also confirmed as the paratype because, despite the fact that MACN-A 3999 is not complete enough to take any of the given measurements, none of these specimens contradicts the diagnosis and both were recognised by Ameghino as "tipo 2 " when he acknowledged the type specimen.

In summary, we confirm MACN-A 4001 as the holotype of Pa. leptocephalus and the individual MACN-A 3999 plus MACN-A 4000 as the paratype of the species.

Chronological and geographical distribution of the type specimen. Santacrucian SALMA, Santa Cruz Province.

\section{Patriarchus icochiloides Ameghino, 1894a}

Holotype. MACN-A 4021 (Fig. 4 E), right maxillary fragment with alveolus of P1 and series P2-M3, and MACNA 4022 (Fig. 4 F), right mandibular fragment with alveoli of p2-3 and series p4-m3, both of the same individual.

Diagnosis (Ameghino 1894a: 14-15). "Cette espèce forme le passage au genre Icochilus. Les molaires et prémolaires sont égales à celles du genre Protypotherium, mais la mandibule est robuste, avec la branche 
horizontale massive, courte, basse en avant et très haute en arrière comme dans le genre lcochilus. Les séries dentaires supérieures sont fortement arquées. Longueur des sept molaires inférieures, $33 \mathrm{~mm}$. Hauteur de la mandibule: en dessous de la ${ }_{2}$. $11 \mathrm{~mm}$.; en dessous de la partie antérieure de la ${ }_{3} \mathrm{~m} .21 \mathrm{~mm}$ "

English translation. This species represents the passage to the Genus Icochilus. Molars and premolars are equal to those of the genus Protypotherium, but the mandible is robust, with short, massive horizontal ramus, anteriorly low and posteriorly very high as in the Genus Icochilus. The upper tooth row is strongly arched. Length of the seven lower cheek teeth, $33 \mathrm{~mm}$. Height of the mandible: below p2, $11 \mathrm{~mm}$; below the anterior region of m3, 21 $\mathrm{mm}$.

Comments. Ameghino (1894a) did not illustrate any specimen of this species. According to Ameghino's catalogue, the maxillary fragment MACN-A 4021 and the mandibular fragment MACN-A 4022, both of the same individual, are the type materials of this taxon. Instead, Mones (1986) only indicated the former as the type specimen. The upper teeth series of MACN-A 4021 are strongly arched as described by Ameghino (1894a). MACN-A 4022 also matches the original diagnosis (Ameghino 1894a) because, in addition to the typical morphology of lower cheek teeth observed in other species of Protypotherium (see P. antiquum for some general characteristics), the mandible is robust with short and strong horizontal ramus that increases its height backwards, and the measurements available to be taken (length of $\mathrm{p} 2-\mathrm{m} 3=31.2 \mathrm{~mm}$; height of the mandibular ramus below $\mathrm{p} 2$ $=10.81 \mathrm{~mm}$; height of the mandibular ramus below the mesial region of $\mathrm{m} 3=21.6 \mathrm{~mm}$ ) are consistent with those provided by Ameghino (1894a). Regarding the remaining eight specimens assigned to the species in Ameghino's catalogue, all of them are mandibular fragments (e.g., MACN-A 4026, MACN-A 4027, MACN-A 4028, MACN-A 9655 and MACN-A 9656) and even the measurements that can be taken (height of the mandibular ramus below $\mathrm{p} 2$ $=14 \mathrm{~mm}$ in MACN-A 4023, height of the mandibular ramus below $\mathrm{m} 3=17.87 \mathrm{~mm}$ in MACN-A 4024, $18.43 \mathrm{~mm}$ in MACN-A 4025 and $18.90 \mathrm{~mm}$ in MACN-A 4028) are not consistent with the type specimen, which leads to discard these materials as types. Consequently, the individual MACN-A 4021 plus MACN-A 4022 is confirmed as the holotype of $P$ a. icochiloides.

Chronological and geographical distribution of the type specimen. Santacrucian SALMA, Santa Cruz Province.

\section{Conclusions}

The main conclusions of this contribution are summarised in Table 1. Despite the fact that Ameghino sold many of the specimens of his private collection, as mentioned above, we can ascertain that he kept the type materials of ten species of Protypotherium and eight of Patriarchus in his personal collection (Table 1), which is nowadays housed at the MACN. Among them, the holotype of Protypotherium australe has not been found, but two type casts are fortunately preserved in the Ameghino Collection. Just in the case of Protypotherium antiquum, its lectotype, which is designated in this contribution, has been located in a foreign institution, the Zoological Museum of the University of Copenhagen in Denmark. This fact is a consequence of a collection sale made by Dr. Roth, who collected the specimen and kept it privately.

For 13 of the 18 species of Protypotherium (8) and Patriarchus (5) in MACN-A, the status of their type specimens is confirmed, meaning that the material catalogued as type by Ameghino, and in some cases confirmed by Mones (1986), was in fact the specimen originally used by the palaeontologist to characterise the species (Table 1).

For the remaining five species, two situations are identified. On the one hand, P. obstructum and P. distortus did not have any type material assigned in Ameghino's catalogue, but we have located it among the specimens labelled as such species (Table 1). On the other hand, the type material catalogued for Protypotherium australe, $P$. convexidens and Patriarchus palmidens is wrongly identified, because the specimens do not match the respective original descriptions (Table 1). In these three cases, the types are also identified among the sample of each species (as casts in the case of P. australe).

\section{Acknowledgements}

We thank the editorial staff and the reviewers (D. Croft and an anonymous one), for their useful comments on this 
manuscript. We are grateful to the curator A. Kramarz (MACN) for making available the collections under his care, and to S. M. Alvarez for her help and goodwill during her time working at the MACN. We are indebted to B. E. Kramer, Collection manager-vertebrate palaeontology, for providing remarkable information and photographs of $P$. antiquum, and to K. L. Hansen for taking such photographs, both from the Zoological Museum of the University of Copenhagen. This work was partially supported by Universidad Nacional de Luján, grants CCD-CD: 054/12 and CONICET-PIP 781 to J.C. Fernicola.

TABLE 1. Summary of the type specimens of each species of Protypotherium and Patriarchus, according to our results, compared with the status of the materials following Ameghino's catalogue and Mones (1986).

\begin{tabular}{|c|c|c|c|c|}
\hline \multirow[t]{2}{*}{ Species } & \multirow[t]{2}{*}{ Specimen } & \multicolumn{3}{|l|}{ Status according to: } \\
\hline & & Ameghino's Catalogue & $\begin{array}{l}\text { Mones } \\
(1986)\end{array}$ & This paper \\
\hline \multirow[t]{4}{*}{ Protypotherium antiquum } & ZMK 21/1877 & ----- & ----- & Lectotype \\
\hline & MACN-A 1288 (cast) & ----- & ----- & Cast type \\
\hline & MLP 97-XI-20-1 (cast) & ----- & ----- & Cast type \\
\hline & Toothless symphysis & ----- & ----- & $\begin{array}{l}\text { Paralectotype } \\
\text { (not found) }\end{array}$ \\
\hline \multirow[t]{4}{*}{ Protypotherium australe } & MACN-A 3882 & Type & ----- & Rejected \\
\hline & MACN-A 3884 & Type & ----- & Rejected \\
\hline & MACN-A 1338 (cast) & ----- & ---- & Cast type \\
\hline & MACN-A 1345-46 (cast) & $\begin{array}{l}\text { Cast type of Toxodontophanus } \\
\text { australis }\end{array}$ & ----- & Cast type \\
\hline \multirow[t]{14}{*}{ Protypotherium praerutilum } & MACN-A 1081 & Type & ----- & Holotype \\
\hline & MACN-A 1082 & Type & ----- & Holotype \\
\hline & MLP 12-1815 & Paratype & ----- & Rejected \\
\hline & MLP 12-1818 & Paratype & ----- & Rejected \\
\hline & MLP 12-1819 & Paratype & ----- & Rejected \\
\hline & MLP 12-1834 & Paratype & ----- & Rejected \\
\hline & MLP 12-1845 & Paratype & ----- & Rejected \\
\hline & MLP 12-1854 & Paratype & ----- & Rejected \\
\hline & MLP 12-1856 & Paratype & ----- & Rejected \\
\hline & MLP 12-1877 & Paratype & ----- & Rejected \\
\hline & MLP 12-2031 & Paratype & ----- & Rejected \\
\hline & MLP 12-2041 & Paratype & ----- & Rejected \\
\hline & MLP 12-2084 & Paratype & ----- & Rejected \\
\hline & MLP 12-2085 & Paratype & ----- & Rejected \\
\hline \multirow[t]{8}{*}{ Protypotherium attenuatum } & MACN-A 524 & Type & ----- & Syntype \\
\hline & MACN-A 628 & ---- & ----- & Syntype \\
\hline & MLP 12-1822 & Paratype & ----- & Rejected \\
\hline & MLP 12-1823 & Paratype & ----- & Rejected \\
\hline & MLP 12-1830 & Paratype & ----- & Rejected \\
\hline & MLP $12-1841$ to MLP $12-1844$ & Paratypes & ----- & Rejected \\
\hline & MLP 12-1850 & Paratype & ----- & Rejected \\
\hline & MLP 12-1851 & Paratype & ----- & Rejected \\
\hline Protypotherium obstructum & MACN-A 1677 & ---- & Type & Holotype \\
\hline Protypotherium claudum & MACN-A 551 & Type & Type & Holotype \\
\hline
\end{tabular}


TABLE 1. (Continued)

\begin{tabular}{|c|c|c|c|c|}
\hline \multirow[t]{2}{*}{ Species } & \multirow[t]{2}{*}{ Specimen } & \multicolumn{3}{|l|}{ Status according to: } \\
\hline & & Ameghino's Catalogue & $\begin{array}{l}\text { Mones } \\
(1986)\end{array}$ & This paper \\
\hline Protypotherium globosum & MACN-A 4049 & Type & Type & Holotype \\
\hline \multirow[t]{2}{*}{ Protypotherium convexidens } & MACN-A 4050 & Type & Type & Rejected \\
\hline & MACN-A 4054 & ----- & ----- & Holotype \\
\hline Protypotherium diversidens & MACN-A 4052 & Type & Type & Holotype \\
\hline \multirow[t]{2}{*}{ Protypotherium compressidens } & MACN-A 4029 & Type & Type & Holotype \\
\hline & MACN-A 4030 & Type & Type & Holotype \\
\hline \multirow[t]{2}{*}{ Protypotherium lineare } & MACN-A 4038 & Type & Type & Holotype \\
\hline & MACN-A 4039 & Type & Type & Holotype \\
\hline \multirow[t]{4}{*}{ Patriarchus palmidens } & MACN-A 37 & Type & ----- & Rejected \\
\hline & MACN-A 38 & Type & ----- & Rejected \\
\hline & MACN-A 4045 & Type & Type & Rejected (lost) \\
\hline & MACN-A 9651a & ----- & ----- & Holotype \\
\hline \multirow[t]{2}{*}{ Patriarchus furculosus } & MACN-A 3970 to 3976 & Type & ----- & Syntype \\
\hline & MACN-A 3977 & ----- & ----- & Syntype \\
\hline Patriarchus distortus & MACN-A 9634 to 9638 & ----- & ----- & Holotype \\
\hline Patriarchus rectus & MACN-A 4005 to 4007 & Type & Type & Holotype \\
\hline Patriarchus diastematus & MACN-A 4044 & Type & Type & Holotype \\
\hline \multirow[t]{3}{*}{ Patriarchus leptocephalus } & MACN-A 3989 & Type & Type & Holotype \\
\hline & MACN-A 3990 & $2^{\text {nd }}$ type & Type & Paratype \\
\hline & MACN-A 3991 & $2^{\text {nd }}$ type & Type & Paratype \\
\hline \multirow[t]{3}{*}{ Patriarchus altus } & MACN-A 3999 & $2^{\text {nd }}$ type & Type & Paratype \\
\hline & MACN-A 4000 & $2^{\text {nd }}$ type & Type & Paratype \\
\hline & MACN-A 4001 & Type & Type & Holotype \\
\hline \multirow[t]{2}{*}{ Patriarchus icochiloides } & MACN-A 4021 & Type & ----- & Holotype \\
\hline & MACN-A 4022 & Type & Type & Holotype \\
\hline
\end{tabular}

\section{References}

Ameghino, F. (1882) Catálogo explicativo de las colecciones de Antropología prehistórica y de paleontología de Florentino Ameghino, Partido de Mercedes. In: Urioste, C., Ambrosetti, T., Butteler, B., de Toledo, R.A., Ruiz, F., Lainez, M., Schröder, E., Quesada, H., Duggan, M. \& Araujo Muñoz, R.C. (Eds.), Catálogo de la Sección de la provincia de Buenos Aires (República Argentina), en la Exposición Continental Sudamericana. Anexo A, Buenos Aires, pp. 35-42.

Ameghino, F. (1885) Nuevos restos de mamíferos fósiles oligocenos, recogidos por el profesor Pedro Scalabrini y pertenecientes al Museo Provincial de la Ciudad del Paraná. Boletín de la Academia Nacional de Ciencias de Córdoba, 8, 5-207.

Ameghino, F. (1887a) Observaciones generales sobre el orden de mamíferos extinguidos sub-americanos llamados Toxodontes (Toxodontia) y sinopsis de los géneros y especies hasta ahora conocidos. Anales del Museo de La Plata, 1 (1), 1-66.

Ameghino, F. (1887b) Enumeración sistemática de las especies de mamíferos fósiles coleccionados por Carlos Ameghino en los terrenos eocenos de la Patagonia austral y depositados en el Museo La Plata. Boletín del Museo de La Plata, 1, 1-26.

Ameghino, F. (1888) Lista de las especies de mamíferos fósiles del Mioceno superior de Monte Hermoso hasta ahora conocidas. Obras Completas y Correspondencia Científica, 5, 481-496.

Ameghino, F. (1889) Contribución al conocimiento de los mamíferos fósiles de la República Argentina. Actas de la Academia Nacional de Ciencias de Córdoba, 6, i-xxxii, 1-1027, atlas of 98 pls.

Ameghino, F. (1891) Nuevos restos de mamíferos fósiles descubiertos por Carlos Ameghino en el Eoceno inferior de la Patagonia austral. Especies nuevas, adiciones y correcciones. Revista Argentina de Historia Natural, 1 (5), 289-328. 
Ameghino, F. (1894a) Énumération synoptique des espèces de mammifères fossiles des formations éocènes de Patagonie. Coni é hijos, Buenos Aires, 196 pp.

Ameghino, F. (1894b) Enumération synoptique des espèces de mammifères fossiles des formations éocènes de Patagonie. Boletín de la Academia Nacional de Ciencias de Córdoba, 13, 259-445.

Ameghino, F. (1900-1902) L'Age des formations sédimentaires de Patagonie. Anales de la Sociedad Cientifica Argentina, (50, $51 \& 54), 109-229$ (1900); 20-250 (1901) \& 161-342 (1902).

Ameghino, F. (1906) Les formations sédimentaires du Crétacé Superieur et du Tertaire de Patagonie avec un parallele entre leurs faunes mammalogiques et celles de l'ancien continent. Anales del Museo Nacional de Buenos Aires, 15, 1-568.

Bond, M. (2000) Carlos Ameghino y su obra édita. Publicación Especial de la Asociación Paleontológica Argentina, 12 (1), 33-41.

Bordas, A. (1936) Los Peltateloidea de la colección Ameghino. Peltephiloda. (Infraorden de los Xenarthra). Physis, 12 (41), 118.

Cassini, G.H., Cerdeño, E., Villafañe, A.L. \& Muñoz, N.A. (2012) Paleobiology of Santacrucian native ungulates (Meridiungulata: Astrapotheria, Litopterna, and Notoungulata). In: Vizcaíno, S.F, Kay, R.F. \& Bargo, S. (Eds.), Early Miocene Paleobiology in Patagonia, High Latitude Paleocommunities of the Santa Cruz Formation. Cambridge University press, New York, pp. 243-286. https://doi.org/10.1017/cbo9780511667381.015

Ciancio, M.R. \& Carlini, A.A. (2008) Identificación de ejemplares tipo de Dasypodidae (Mammalia, Xenarthra) del Paleógeno de Argentina. Revista del Museo Argentino de Ciencias Naturales, 10 (2), 221-237. https://doi.org/10.22179/REVMACN.10.279

Cione, A.L., Azpelicueta, M.M., Bond, M., Carlini, A.A., Casciotta, J.R., Cozzuol, M.A., de la Fuente, M., Gasparini, Z., Goin, F.J., Noriega, J., Scillato-Yané, G.J., Soibelzon, L., Tonni, E.P., Verzi, D. \& Vucetich, M.G. (2000) Miocene vertebrates from Entre Ríos province, eastern Argentina. In: Aceñolaza, F.G. \& Herbst, R. (Eds.), El Neógeno de Argentina. Vol. 14. INSUGEO, Tucumán, pp. 191-237.

Croft, D.A. \& Anderson, L.C. (2008) Locomotion in the extinct notoungulate Protypotherium. Paleontología Electrónica, 11 (1), 1-20.

Cruz, L.E., Fernicola, J.C. \& Porpino, K.D.O. (2013) A propósito del neotipo de Panochthus tuberculatus (Owen, 1845) (Mammalia, Xenarthra, Glyptodontia). Revista Brasileira de Paleontologia, 16 (2), 331-340. https://doi.org/10.4072/rbp.2013.2.13

De Iuliis, G., Fernicola, J.C. \& Racco, A. (2016) On the Publication and Pagination of Ameghino's (1894) Taxonomy of Santacrucian Mammals. Ameghiniana, 53 (4), 517-522. https://doi.org/10.5710/amgh.26.01.2016.2909

Elissamburu, A. (2012) Estimación de la masa corporal en géneros del Orden Notoungulata. Estudios Geológicos, 68 (1), 91111. https://doi.org/10.3989/egeol.40336.133

Fernández, M., Fernicola, J.C. \& Cerdeño, E. (2013) A propósito de los ejemplares tipo de las especies de Icochilus e Interatherium (Mammalia, Notoungulata, Interatheriidae) erigidas por Florentino Ameghino entre 1887 y 1899. Ameghiniana, 50 (6), 29R.

Fernicola, J.C. (2011a) Implicancias del conflicto Ameghino-Moreno sobre la colección de mamíferos fósiles realizada por Carlos Ameghino en su primera exploración al río Santa Cruz, Argentina. Revista del Museo Argentino de Ciencias Naturales, 13 (1), 41-57.

Fernicola, J.C. (2011b) Ascenso, auge y caída de la sociedad entre Florentino Ameghino y Francisco P. Moreno. Publicación Especial de la Asociación Paleontológica Argentina, 12 (1), 35-49.

Hitz, R., Reguero, M.A., Wyss, A.R. \& Flynn, J.J. (2000) New interatheriines (Interatheriidae, Notoungulata) from the Paleogene of central Chile and southern Argentina. Feldiana, Geology, 42, 1-26.

Hooker, J.J. (1986) Mammals from the Bartonian (middle/late Eocene) of the Hampshire Basin, southern England. Bulletin of the British Museum (Natural History), Geology Series, 39 (4), 191-478.

International Commission of Zoological Nomenclature (2000) International code of zoological nomenclature. $4^{\text {th }}$ Edition. Museo Nacional de Ciencias Naturales, Madrid, 156 pp. [Spanish version]

Luna, D.A. (2015) Miocene ungulates from Laguna del Laja, Chile, and an assessment of the Laguna del Laja fauna. Unpublished Ph.D. dissertation, University of California, Santa Barbara, 287 pp.

Marshall, L.G. (1980) Systematics of the South American marsupial family Caenolestidae. Fieldiana Geology, 5, 1-145. https://doi.org/10.5962/bhl.title.3314

Mones A. (1986) Palaeovertebrata Sudamericana. Catálogo Sistemático de los Vertebrados Fósiles de América del Sur, Parte I. Preliminary List and Bibliography. Courier Forschungsinstitut Senckenberg, 82, 1-625.

Moreno, F.P. (1882) Patagonia, resto de un antiguo continente hoy sumergido. Contribuciones al estudio de las colecciones del Museo Antropológico y Arqueológico de Buenos Aires. Anales de la Sociedad Científica Argentina, 14, 97-131.

Reguero, M.A., Ubilla, M. \& Perea, D. (2003) A new species of Eopachyrucos (Mammalia, Notoungulata, Interatheriidae) from the late Oligocene of Uruguay. Journal of Vertebrate Paleontology, 23 (2), 445-457. https://doi.org/10.1671/0272-4634(2003)023[0445:ansoem]2.0.co;2

Roth, S. (1903) Los ungulados sudamericanos. Anales del Museo de La Plata, 5, 1-36. 
Schmidt, G.I. (2013) Litopterna y Notoungulata (Mammalia) de la Formación Ituzaingó (Mioceno Tardío-Plioceno) de la Provincia de Entre Ríos: sistemática, bioestratigrafia y paleobiogeografía. Unpublished Ph.D. dissertation, Universidad Nacional de La Plata, La Plata, 336 pp.

Simpson, G.G. (1984) Discoverers of the lost World: An Account of Some of Those who Brought Back to Life South American Mammals Long Buried in the Abyss of Time. Yale University Press, New Haven \& London, 222 pp.

Smith, J.B. \& Dodson, P. (2003) A proposal for a standard terminology of anatomical notation and orientation in fossil vertebrate dentitions. Journal of Vertebrate paleontology, 23 (1), 1-12. https://doi.org/10.1671/0272-4634(2003)23[1:apfast]2.0.co;2

Townsend, K.E. \& Croft, D.A. (2008) Diets of notoungulates from the Santa Cruz Formation, Argentina: new evidence from enamel microwear. Journal of Vertebrate Paleontology, 28 (1), 217-230. https://doi.org/10.1671/0272-4634(2008)28[217:donfts]2.0.co;2

Vera, B. \& Cerdeño, E. (2014) Systematic revision of Antepithecus brachystephanus Ameghino, 1901, and dental eruption sequence in Eocene "notopithecines" (Notoungulata) from Patagonia. Geobios, 47 (3), 165-181. https://doi.org/10.1016/j.geobios.2014.02.001

Vizcaíno, S.F. (2011) Cartas para Florentino desde Patagonia. Crónica de la correspondencia édita entre los hermanos Ameghino (1882-1902). Publicación Electrónica de la Asociación Paleontológica Argentina, 12 (1), 51-67.

Vizcaíno, S.F., Bargo, M.S. \& Fernicola, J.C. (2013) Expediciones paleontológicas durante los Siglos XIX y XX a la Formación Santa Cruz (Mioceno Inferior, Patagonia) y destino de los fósiles. Actas del $3^{\text {er }}$ Congreso Argentino de Historia de la Geología, Salta, 2013, 1-15.

Zittel, K.A. (1893) Handbuch der Palaeontologie. Vol 4. Vertebrata (Mammalia). Oldenbourg, München, 293 pp. 